\title{
Use of IL-23 Inhibitors for the Treatment of Plaque Psoriasis and Psoriatic Arthritis: A Comprehensive Review
}

\author{
Kevin Yang ${ }^{1}$ - Allen S. W. Oak ${ }^{1}$ (1) $\cdot$ Boni E. Elewski ${ }^{1}$
}

Published online: 10 December 2020

C) Springer Nature Switzerland AG 2020

\begin{abstract}
Psoriasis is a common inflammatory skin disease with multiple comorbidities, including psoriatic arthritis and coronary artery disease, that can severely impact an individual's quality of life and daily functioning. In recent years, enhanced understanding of the pathogenesis of psoriasis, especially the role of $\mathrm{T}$ helper 17 cells, has resulted in the development of new classes of biologic drugs targeting modulators along its disease pathway. Among these, inhibitors of interleukin-23 (e.g., ustekinumab, guselkumab, tildrakizumab, and risankizumab) have emerged as safe and effective options for the treatment of moderate-tosevere plaque psoriasis; ustekinumab and guselkumab have additionally been approved to treat psoriatic arthritis. Selective interleukin-23 inhibitors require less frequent dosing than interleukin-17 inhibitors and may possess a more favorable risk profile without an increased risk of candidiasis or inflammatory bowel disease. Overall, these highly effective medications are contributing to a rising standard for psoriasis outcomes through resolution of skin lesions and joint manifestations and improvement of patient quality of life.
\end{abstract}

\section{Key Points}

Interleukin (IL)-23 plays an important role in the development of psoriasis and psoriatic arthritis.

IL-23 inhibitors are effective in treating psoriasis and psoriatic arthritis.

IL-23 inhibitors are safe and do not show a significantly increased risk for adverse events.

\section{Introduction}

Psoriasis is a chronic inflammatory disease affecting over 7 million people in the USA with an estimated annual financial burden of over US $\$ 112$ billion [1,2]. Plaque psoriasis is the most common subtype and classically manifests as

Allen S. W. Oak

siwonoak@uabmc.edu

1 Department of Dermatology, University of Alabama at Birmingham, Birmingham, AL 35294, USA erythematous plaques with an overlying micaceous silvery scale on the trunk and extensor surfaces of the extremities; less common subtypes include inverse, guttate, and pustular [3, 4]. Nail lesions, such as pitting and onycholysis, may also be seen. Psoriasis is also associated with multiple comorbidities, including cardiovascular disease, metabolic syndrome, psychiatric conditions, malignancy, renal disease, and hepatic disease [5].

Psoriatic arthritis (PsA) is an inflammatory arthritis that may co-occur in up to a third of patients with psoriasis [6]. Psoriatic arthritis clinically presents with dactylitis, as well as enthesitis of the plantar fascia and Achilles tendon [7]. Psoriatic arthritis usually arises approximately 10 years after the onset of psoriatic lesions. However, it may precede the skin findings in $15 \%$ of cases [7]. Psoriatic arthritis may be difficult to distinguish from other inflammatory arthritides, but the morbidity of the disease warrants a low threshold for initiation of therapy.

The pathogenesis of psoriasis stems from dysregulation of the immune system, resulting in chronic inflammation and uncontrolled keratinocyte proliferation. Early studies demonstrated the presence and potential interaction of dendritic cells and $\mathrm{T}$ lymphocytes in psoriatic lesions $[8,9]$. Originally, $\mathrm{T}$ helper 1 cells, activated by dendritic cell-produced interleukin (IL)-12, were implicated in psoriasis via production of tumor necrosis factor- $\alpha$ (TNF- $\alpha)$ and interferon- $\gamma$; 
however, these cytokines showed no involvement in regulating keratinocyte proliferation [10-12]. Subsequently, the subset of T helper cells known as T helper 17 (Th17) cells and its production of IL-17 and IL-22 were identified to be central in driving psoriasis [13-17]. In particular, keratinocytes are stimulated to increase chemokine expression that perpetuates recruitment of Th17 cells $[18,19]$. Upstream of this key component, dendritic cells produce IL-23 to promote differentiation and proliferation of the Th17 cells [20, 21]. Interestingly, a novel study reporting single-cell RNA sequencing of psoriatic human epidermis identified elevated populations of proliferative and ion channel genes. In addition, psoriatic epidermis was also found to be enriched for

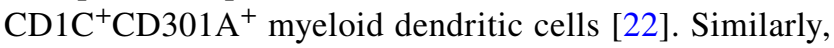
Th17 cells have been heavily associated with the pathogenesis of PsA [23, 24]. While incompletely understood, PsA is generally thought to result from migration of dendritic cells out of the skin into the joint space, resulting in chronic inflammation in the synovial fluid [25, 26]. Further, IL-22 plays a role in upregulating RANKL to induce osteoclast formation, bone erosion, and new bone formation [27, 28].
Treatment of psoriasis has traditionally focused on suppressing the immune system and keratinocyte proliferation, such as with methotrexate, cyclosporine, and acitretin. With elucidation of the immunological processes underlying psoriasis, biologic drugs have rapidly come to the forefront for targeting of modulators along these pathways, including TNF- $\alpha$, IL-17, and IL-23. In the last 5 years, seven biologic drugs have been approved by the US Food and Drug Administration (FDA) to treat plaque psoriasis (Table 1). Ustekinumab, approved by the FDA in 2009, targets the p40 subunit shared by IL-23 and IL- 12 . We include ustekinumab in this review because it is partially an IL-23 inhibitor.

Guselkumab, tildrakizumab, and risankizumab have been approved in the last 3 years with targeting of the p19 subunit of IL-23 (Table 2). At the time of this writing, mirikizumab remains under development. This review evaluates the efficacy and safety of IL-23 inhibitors in the treatment of plaque psoriasis and psoriatic arthritis.

Table 1 US Food and Drug Administration (FDA)-approved biologic drugs

\begin{tabular}{|c|c|c|c|}
\hline Drug & Mechanism & Route of administration & $\begin{array}{l}\text { Year of } \\
\text { FDA } \\
\text { approval }\end{array}$ \\
\hline \multicolumn{4}{|c|}{ FDA-approved biologic drugs for plaque psoriasis } \\
\hline Risankizumab & Humanized IgG1 monoclonal antibody binding p19 subunit of IL-23 & Subcutaneous & 2019 \\
\hline Certolizumab & Humanized PEGylated Fab fragment binding TNF- $\alpha$ & Subcutaneous & 2018 \\
\hline Tildrakizumab & 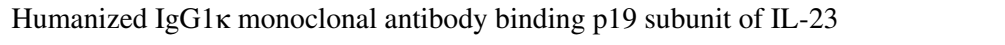 & Subcutaneous & 2018 \\
\hline Guselkumab & Human IgG1 $\lambda$ monoclonal antibody binding p19 subunit of IL-23 & Subcutaneous & 2017 \\
\hline Brodalumab & Human monoclonal IgG2 antibody binding IL-17RA & Subcutaneous & 2017 \\
\hline Ixekizumab & Humanized IgG4 monoclonal antibody binding IL-17A & Subcutaneous & 2016 \\
\hline Secukinumab & Human IgG1 monoclonal antibody binding IL-17A & Subcutaneous & 2015 \\
\hline Ustekinumab & Human $\operatorname{IgG} 1 \kappa$ monoclonal antibody binding shared p 40 subunit of IL- 12 and IL-23 & Subcutaneous & 2009 \\
\hline Adalimumab & Human IgG1 monoclonal antibody binding TNF- $\alpha$ & Subcutaneous & 2008 \\
\hline Infliximab & 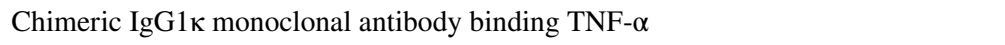 & Intravenous & 2006 \\
\hline Etanercept & Decoy TNF receptor & Subcutaneous & 2004 \\
\hline \multicolumn{4}{|c|}{ FDA-approved biologic drugs for psoriatic arthritis } \\
\hline Guselkumab & Human $\operatorname{IgG} 1 \lambda$ monoclonal antibody binding p19 subunit of IL-23 & Subcutaneous & 2020 \\
\hline Ixekizumab & Humanized IgG4 monoclonal antibody binding IL-17A & Subcutaneous & 2017 \\
\hline Abatacept & Binds CD80 and CD86 & Intravenous/subcutaneous & 2017 \\
\hline Secukinumab & Human IgG1 monoclonal antibody binding IL-17A & Subcutaneous & 2016 \\
\hline Certolizumab & Humanized PEGylated Fab fragment binding TNF- $\alpha$ & Subcutaneous & 2013 \\
\hline Ustekinumab & 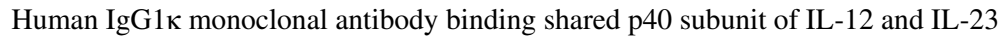 & Subcutaneous & 2013 \\
\hline Golimumab & 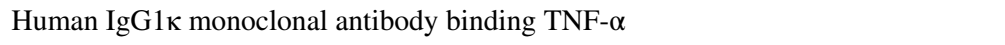 & Subcutaneous & 2009 \\
\hline Adalimumab & Human IgG1 monoclonal antibody binding TNF- $\alpha$ & Subcutaneous & 2005 \\
\hline Infliximab & 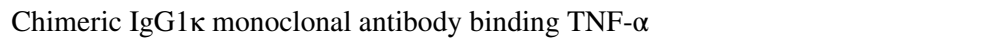 & Intravenous & 2005 \\
\hline Etanercept & Decoy TNF receptor & Subcutaneous & 2002 \\
\hline
\end{tabular}

$I g G$ immunoglobulin G, $I L$ interleukin, $I L-17 R A$ interleukin-17A receptor, $T N F$ tumor necrosis factor 
Table 2 Basic data of interleukin-23 inhibitors

\begin{tabular}{|c|c|c|c|c|c|c|}
\hline Drug & Available forms & Dosing & Indications & Bioavailability (\%) & Time to peak (days) & $\begin{array}{l}\text { Half-life } \\
\text { elimination } \\
\text { (days) }\end{array}$ \\
\hline Ustekinumab & $\begin{array}{l}\text { Subcutaneous (90 } \\
\mathrm{mg} / \mathrm{mL}) \text { or intrave- } \\
\text { nous }(5 \mathrm{mg} / \mathrm{mL})\end{array}$ & $\begin{array}{l}\text { For patients } \leq 100 \mathrm{~kg} \text {, } \\
45 \mathrm{mg} \text { subcutane- } \\
\text { ously at } 0 \text { and } 4 \\
\text { weeks, then every } \\
12 \text { weeks; for } \\
\text { patients }>100 \mathrm{~kg} \text {, } \\
90 \mathrm{mg} \text { subcutane- } \\
\text { ously at } 0 \text { and } 4 \\
\text { weeks, then every } \\
12 \text { weeks }\end{array}$ & $\begin{array}{l}\text { Moderate-to-severe } \\
\text { plaque psoriasis, } \\
\text { psoriatic arthritis, } \\
\text { moderate-to-severe } \\
\text { Crohn's disease, } \\
\text { and ulcerative } \\
\text { colitis }\end{array}$ & 57 [93] & $\begin{array}{l}13.5(45 \mathrm{mg}) ; 7 \text { (90 } \\
\mathrm{mg})\end{array}$ & $14.9-45.6$ \\
\hline Guselkumab & $\begin{array}{l}\text { Subcutaneous (100 } \\
\mathrm{mg} / \mathrm{mL})\end{array}$ & $\begin{array}{l}\text { 100mg subcutane- } \\
\text { ously at } 0 \text { and } 4 \\
\text { weeks, then every } 8 \\
\text { weeks }\end{array}$ & $\begin{array}{c}\text { Moderate-to-severe } \\
\text { plaque psoriasis }\end{array}$ & 49 & 5.5 & $15-18$ \\
\hline Tildrakizumab & $\begin{array}{l}\text { Subcutaneous }(100 \\
\mathrm{mg} / \mathrm{mL})\end{array}$ & $\begin{array}{l}100 \mathrm{mg} \text { subcutane- } \\
\text { ously at } 0 \text { and } 4 \\
\text { weeks, then every } \\
12 \text { weeks }\end{array}$ & $\begin{array}{c}\text { Moderate-to-severe } \\
\text { plaque psoriasis }\end{array}$ & $73-80$ & 6 & 23 \\
\hline Risankizumab & $\begin{array}{l}\text { Subcutaneous (75 } \\
\mathrm{mg} / 0.83 \mathrm{~mL})\end{array}$ & $\begin{array}{l}150 \mathrm{mg} \text { subcutane- } \\
\text { ously at } 0 \text { and } 4 \\
\text { weeks, then every } \\
12 \text { weeks }\end{array}$ & $\begin{array}{l}\text { Moderate-to-severe } \\
\text { plaque psoriasis }\end{array}$ & 89 & $3-14$ & 28 \\
\hline
\end{tabular}

Information from package inserts unless referenced otherwise [119-122]

\section{Literature Search Methods}

A literature search of PubMed was conducted for the terms "ustekinumab", "guselkumab", "tildrakizumab", and "risankizumab". Randomized controlled studies, openlabel extension studies, conference abstracts, and press releases up to October 2020 were included. References of identified articles were searched for additional articles. Package inserts provided by the pharmaceutical companies producing the drugs were reviewed as well.

\section{Treatment of Plaque Psoriasis}

Phase II and III clinical trials investigating the efficacy of IL-23 inhibitors against placebo or comparators were identified (Tables 3, 4, 5). Primary endpoints focused on improvement from baseline Psoriasis Area and Severity Index (PASI) scores, for example, PASI 75, 90, and 100 for corresponding improvement response percentage. PASI scores are based on the extent and severity of erythema, induration, and desquamation on the head, arms, trunk, and legs. Inclusion criteria for the studies generally required diagnosis of psoriasis for 6 months involving $\geq 10 \%$ body surface area and a baseline PASI score $\geq 12$.

\subsection{Ustekinumab}

Ustekinumab is a fully human, $\operatorname{IgG} 1 \kappa$ monoclonal antibody that binds to the shared p40 subunit of IL-12 and IL-23. Krueger et al. first demonstrated the efficacy of ustekinumab over placebo. Three hundred and twenty patients were randomly assigned to placebo or ustekinumab (once at 45 or 90 $\mathrm{mg}$, or four weekly doses at 45 or $90 \mathrm{mg}$ ). PASI 75 at week 12 was achieved by all treatment groups with four-weekly doses at $90 \mathrm{mg}$ representing the best results at $81 \%$. Patientreported quality-of-life assessments were also improved with ustekinumab treatment [29].

Ustekinumab was subsequently evaluated in the phase III trials PHOENIX 1 and 2. In these trials, 1996 total patients were randomized to placebo or ustekinumab at 45 or $90 \mathrm{mg}$ at 0 and 4 weeks, then every 12 weeks. The primary endpoint, PASI 75 at week 12, was met across all treatment groups in both trials with $66 \%$ and $67 \%$ at $45 \mathrm{mg}$ and 66 and $76 \%$ at $90 \mathrm{mg}$. Results were consistent with the PASI 90 and 100 endpoints [30, 31]. The ACCEPT trial was conducted for a head-to-head comparison of ustekinumab with the TNF- $\alpha$ inhibitor etanercept. Nine hundred and seven patients were randomly assigned to receive etanercept $(50 \mathrm{mg}$ twice weekly) or ustekinumab (45 or $90 \mathrm{mg}$ at 0 and 4 weeks, then every 12 weeks). PASI 75 at week 12 was achieved by $68 \%$ at $45 \mathrm{mg}$ and $74 \%$ at $90 \mathrm{mg}$ ustekinumab compared with $57 \%$ by etanercept, meeting the primary endpoint of the 
Table 3 Psoriasis Area Severity Index (PASI) results of interleukin-23 inhibitors at 16 weeks

\begin{tabular}{|c|c|c|c|c|}
\hline Study & Dosing or cohort & PASI $75(\%)$ & PASI $90(\%)$ & PASI $100(\%)$ \\
\hline \multicolumn{5}{|l|}{ Ustekinumab } \\
\hline \multirow[t]{5}{*}{ Krueger et al. $^{\text {a }}$ [29] } & $\begin{array}{l}\text { Placebo } \\
n=64\end{array}$ & 1.6 & 1.6 & 0.0 \\
\hline & $\begin{array}{l}45 \mathrm{mg} \text { at } 0 \text { weeks } \\
n=64\end{array}$ & 51.6 & 23.4 & 4.7 \\
\hline & $\begin{array}{l}90 \mathrm{mg} \text { at } 0 \text { weeks } \\
n=64\end{array}$ & 59.4 & 29.7 & 15.6 \\
\hline & $\begin{array}{l}45 \mathrm{mg} \text { at } 0,1,2 \text {, and } 3 \text { weeks } \\
n=64\end{array}$ & 67.2 & 43.8 & 15.6 \\
\hline & $\begin{array}{l}90 \mathrm{mg} \text { at } 0,1,2, \text { and } 3 \text { weeks } \\
n=64\end{array}$ & 81.3 & 51.6 & 20.3 \\
\hline \multirow[t]{3}{*}{ PHOENIX 1a [30] } & $\begin{array}{l}\text { Placebo } \\
n=255\end{array}$ & 3.1 & 2.0 & 0.0 \\
\hline & $\begin{array}{l}45 \mathrm{mg} \text { at } 0 \text { and } 4 \text { weeks, then every } 12 \text { weeks } \\
n=255\end{array}$ & 67.1 & 41.6 & 12.5 \\
\hline & $\begin{array}{l}90 \mathrm{mg} \text { at } 0 \text { and } 4 \text { weeks, then every } 12 \text { weeks } \\
n=256\end{array}$ & 66.4 & 36.7 & 10.9 \\
\hline \multirow[t]{3}{*}{ PHOENIX 2 ${ }^{\mathrm{a}}$ [31] } & $\begin{array}{l}\text { Placebo } \\
n=410\end{array}$ & 3.7 & 0.7 & 0.0 \\
\hline & $\begin{array}{l}45 \mathrm{mg} \text { at } 0 \text { and } 4 \text { weeks, then every } 12 \text { weeks } \\
n=409\end{array}$ & 66.7 & 42.3 & 18.1 \\
\hline & $\begin{array}{l}90 \mathrm{mg} \text { at } 0 \text { and } 4 \text { weeks, then every } 12 \text { weeks } \\
n=411\end{array}$ & 75.7 & 50.9 & 18.2 \\
\hline \multirow[t]{3}{*}{ ACCEPT $^{\mathrm{a}}[32]$} & $\begin{array}{l}45 \mathrm{mg} \text { at } 0 \text { and } 4 \text { weeks, then every } 12 \text { weeks } \\
n=209\end{array}$ & 67.5 & 36.4 & NA \\
\hline & $\begin{array}{l}90 \mathrm{mg} \text { at } 0 \text { and } 4 \text { weeks, then every } 12 \text { weeks } \\
n=347\end{array}$ & 73.8 & 44.7 & NA \\
\hline & $\begin{array}{l}\text { Comparator }{ }^{\mathrm{b}}: \text { etanercept } \\
n=347\end{array}$ & 56.8 & 23.1 & NA \\
\hline \multirow[t]{2}{*}{ PEARL $^{\mathrm{a}}[35]$} & $\begin{array}{l}\text { Placebo } \\
n=60\end{array}$ & 5.0 & 1.7 & 0.0 \\
\hline & $\begin{array}{l}45 \mathrm{mg} \text { at } 0 \text { and } 4 \text { weeks, then every } 12 \text { weeks } \\
n=61\end{array}$ & 67.2 & 49.2 & 8.2 \\
\hline \multirow[t]{3}{*}{ Igarashi et al. $^{\mathrm{a}}$ [36] } & $\begin{array}{l}\text { Placebo } \\
n=31\end{array}$ & 6.5 & 3.2 & NA \\
\hline & $\begin{array}{l}45 \mathrm{mg} \text { at } 0 \text { and } 4 \text { weeks, then every } 12 \text { weeks } \\
n=64\end{array}$ & 59.4 & 32.8 & NA \\
\hline & $\begin{array}{l}90 \mathrm{mg} \text { at } 0 \text { and } 4 \text { weeks, then every } 12 \text { weeks } \\
n=62\end{array}$ & 67.7 & 43.5 & NA \\
\hline \multirow[t]{2}{*}{ LOTUS $^{\mathrm{a}}$ [37] } & $\begin{array}{l}\text { Placebo } \\
n=162\end{array}$ & 11.1 & 3.1 & 0.6 \\
\hline & $\begin{array}{l}45 \mathrm{mg} \text { at } 0 \text { and } 4 \text { weeks, then every } 12 \text { weeks } \\
n=160\end{array}$ & 82.5 & 66.9 & 23.8 \\
\hline \multicolumn{5}{|l|}{ Guselkumab } \\
\hline \multirow[t]{5}{*}{ X-PLORE [40] } & $\begin{array}{l}\text { Placebo } \\
n=42\end{array}$ & 4.8 & 2.4 & 0.0 \\
\hline & $\begin{array}{l}5 \mathrm{mg} \text { at } 0 \text { and } 4 \text { weeks, then every } 12 \text { weeks } \\
n=41\end{array}$ & 43.9 & 34.1 & 9.8 \\
\hline & $\begin{array}{l}15 \text { mg every } 8 \text { weeks } \\
n=41\end{array}$ & 75.6 & 34.1 & 12.2 \\
\hline & $\begin{array}{l}50 \mathrm{mg} \text { at } 0 \text { and } 4 \text { weeks, then every } 12 \text { weeks } \\
n=42\end{array}$ & 81.0 & 45.2 & 19.0 \\
\hline & $\begin{array}{l}100 \mathrm{mg} \text { every } 8 \text { weeks } \\
n=42\end{array}$ & 78.6 & 61.9 & 33.3 \\
\hline
\end{tabular}


Table 3 (continued)

\begin{tabular}{|c|c|c|c|c|}
\hline Study & Dosing or cohort & PASI $75(\%)$ & PASI $90(\%)$ & PASI $100(\%)$ \\
\hline & $\begin{array}{l}200 \mathrm{mg} \text { at } 0 \text { and } 4 \text { weeks, then every } 12 \text { weeks } \\
n=42\end{array}$ & 81.0 & 57.1 & 28.6 \\
\hline & $\begin{array}{l}\text { Comparator }{ }^{\mathrm{b}}: \text { adalimumab } \\
n=43\end{array}$ & 69.8 & 44.2 & 25.6 \\
\hline \multirow[t]{3}{*}{ VOYAGE 1 [41] } & $\begin{array}{l}\text { Placebo } \\
n=174\end{array}$ & 5.7 & 2.9 & 0.6 \\
\hline & $\begin{array}{l}100 \mathrm{mg} \text { at } 0 \text { and } 4 \text { weeks, then every } 8 \text { weeks } \\
n=329\end{array}$ & 91.2 & 73.3 & 37.4 \\
\hline & $\begin{array}{l}\text { Comparator }{ }^{\text {b: }} \text { adalimumab } \\
n=334\end{array}$ & 73.1 & 49.7 & 17.1 \\
\hline \multirow[t]{3}{*}{ VOYAGE 2 [42] } & $\begin{array}{l}\text { Placebo } \\
n=248\end{array}$ & 8.1 & 2.4 & 0.8 \\
\hline & $\begin{array}{l}100 \mathrm{mg} \text { at } 0 \text { and } 4 \text { weeks, then every } 8 \text { weeks } \\
n=496\end{array}$ & 86.3 & 70.0 & 34.1 \\
\hline & $\begin{array}{l}\text { Comparator }{ }^{\mathrm{b}}: \text { adalimumab } \\
n=248\end{array}$ & 68.5 & 46.8 & 20.6 \\
\hline \multirow[t]{3}{*}{ Ohtsuki et al. [46] } & $\begin{array}{l}\text { Placebo } \\
n=64\end{array}$ & 6.3 & 0.0 & 0.0 \\
\hline & $\begin{array}{l}50 \mathrm{mg} \text { at } 0 \text { and } 4 \text { weeks, then every } 8 \text { weeks } \\
n=65\end{array}$ & 89.2 & 70.8 & 32.3 \\
\hline & $\begin{array}{l}100 \mathrm{mg} \text { at } 0 \text { and } 4 \text { weeks, then every } 8 \text { weeks } \\
n=63\end{array}$ & 84.1 & 69.8 & 27.0 \\
\hline \multirow[t]{2}{*}{ ECLIPSE $^{\mathrm{a}}[45]$} & $\begin{array}{l}100 \mathrm{mg} \text { at } 0 \text { and } 4 \text { weeks, then every } 8 \text { weeks } \\
n=534\end{array}$ & 89.3 & 69.1 & NA \\
\hline & $\begin{array}{l}\text { Comparator }{ }^{\text {b: }}: \text { secukinumab } \\
n=514\end{array}$ & 91.6 & 76.1 & NA \\
\hline \multirow[t]{2}{*}{ ORION [48] } & $\begin{array}{l}\text { Placebo } \\
n=16\end{array}$ & 0.0 & 0.0 & 0.0 \\
\hline & $\begin{array}{l}100 \mathrm{mg} \text { at } 0 \text { and } 4 \text { weeks, then every } 8 \text { weeks } \\
n=62\end{array}$ & 88.7 & 75.8 & 50.0 \\
\hline \multicolumn{5}{|l|}{ Tildrakizumab } \\
\hline \multirow[t]{5}{*}{ Papp et al. [49] } & $\begin{array}{l}\text { Placebo } \\
n=45\end{array}$ & 4.4 & 2.4 & NA \\
\hline & $\begin{array}{l}5 \mathrm{mg} \text { at } 0 \text { and } 4 \text { weeks, then every } 12 \text { weeks } \\
n=42\end{array}$ & 33.3 & 12.5 & NA \\
\hline & $\begin{array}{l}25 \mathrm{mg} \text { at } 0 \text { and } 4 \text { weeks, then every } 12 \text { weeks } \\
n=90\end{array}$ & 64.4 & 25.3 & NA \\
\hline & $\begin{array}{l}100 \mathrm{mg} \text { at } 0 \text { and } 4 \text { weeks, then every } 12 \text { weeks } \\
n=89\end{array}$ & 66.3 & 38.6 & NA \\
\hline & $\begin{array}{l}200 \mathrm{mg} \text { at } 0 \text { and } 4 \text { weeks, then every } 12 \text { weeks } \\
n=86\end{array}$ & 74.4 & 52.4 & NA \\
\hline \multirow[t]{3}{*}{ reSURFACE $1^{\mathrm{a}}[50]$} & $\begin{array}{l}\text { Placebo } \\
n=154\end{array}$ & 5.8 & 2.6 & 1.3 \\
\hline & $\begin{array}{l}100 \mathrm{mg} \text { at } 0 \text { and } 4 \text { weeks, then every } 12 \text { weeks } \\
n=309\end{array}$ & 63.8 & 34.6 & 13.9 \\
\hline & $\begin{array}{l}200 \mathrm{mg} \text { at } 0 \text { and } 4 \text { weeks, then every } 12 \text { weeks } \\
n=308\end{array}$ & 62.3 & 35.4 & 14.0 \\
\hline \multirow[t]{4}{*}{ reSURFACE $2^{\mathrm{a}}[50]$} & $\begin{array}{l}\text { Placebo } \\
n=156\end{array}$ & 5.8 & 1.3 & 0.0 \\
\hline & $\begin{array}{l}100 \mathrm{mg} \text { at } 0 \text { and } 4 \text { weeks, then every } 12 \text { weeks } \\
n=307\end{array}$ & 61.2 & 38.8 & 12.4 \\
\hline & $\begin{array}{l}200 \mathrm{mg} \text { at } 0 \text { and } 4 \text { weeks, then every } 12 \text { weeks } \\
n=314\end{array}$ & 65.6 & 36.6 & 11.8 \\
\hline & $\begin{array}{l}\text { Comparator }{ }^{\mathrm{b}}: \text { etanercept } \\
n=313\end{array}$ & 48.2 & 21.4 & 4.8 \\
\hline
\end{tabular}


Table 3 (continued)

\begin{tabular}{|c|c|c|c|c|}
\hline Study & Dosing or cohort & PASI $75(\%)$ & PASI $90(\%)$ & PASI $100(\%)$ \\
\hline \multicolumn{5}{|l|}{ Risankizumab } \\
\hline \multirow[t]{4}{*}{ Papp et al. ${ }^{\mathrm{a}}$ [52] } & $\begin{array}{l}18 \mathrm{mg} \text { at } 0 \text { weeks } \\
n=43\end{array}$ & 62.8 & 32.6 & 14.0 \\
\hline & $\begin{array}{l}90 \mathrm{mg} \text { at } 0,4, \text { and } 16 \text { weeks } \\
n=41\end{array}$ & 97.6 & 73.2 & 41.5 \\
\hline & $\begin{array}{l}180 \mathrm{mg} \text { at } 0,4, \text { and } 16 \text { weeks } \\
n=42\end{array}$ & 88.1 & 81.0 & 47.6 \\
\hline & $\begin{array}{l}\text { Comparator }{ }^{\text {b: }} \text { ustekinumab } \\
n=40\end{array}$ & 72.5 & 40.0 & 17.5 \\
\hline \multirow[t]{3}{*}{ UltIMMa-1 [53] } & $\begin{array}{l}\text { Placebo } \\
n=102\end{array}$ & 9 & 4.9 & 0.0 \\
\hline & $\begin{array}{l}150 \mathrm{mg} \text { at } 0 \text { and } 4 \text { weeks, then every } 12 \text { weeks } \\
n=304\end{array}$ & 89 & 75.3 & 35.9 \\
\hline & $\begin{array}{l}\text { Comparator }{ }^{\mathrm{b}}: \text { ustekinumab } \\
n=100\end{array}$ & 76 & 42.0 & 12.0 \\
\hline \multirow[t]{3}{*}{ UltIMMa-2 [53] } & $\begin{array}{l}\text { Placebo } \\
n=98\end{array}$ & 6 & 2.0 & 2.0 \\
\hline & $\begin{array}{l}150 \mathrm{mg} \text { at } 0 \text { and } 4 \text { weeks, then every } 12 \text { weeks } \\
n=294\end{array}$ & 91 & 74.8 & 50.7 \\
\hline & $\begin{array}{l}\text { Comparator }{ }^{\text {a }}: \text { ustekinumab } \\
n=99\end{array}$ & 70 & 47.5 & 24.2 \\
\hline \multirow[t]{3}{*}{ SustaIMM [56] } & $\begin{array}{l}\text { Placebo } \\
n=58\end{array}$ & 8.6 & 1.7 & 0.0 \\
\hline & $\begin{array}{l}75 \mathrm{mg} \text { at } 0 \text { and } 4 \text { weeks, then every } 12 \text { weeks } \\
n=58\end{array}$ & 89.7 & 75.9 & 22.4 \\
\hline & $\begin{array}{l}150 \mathrm{mg} \text { at } 0 \text { and } 4 \text { weeks, then every } 12 \text { weeks } \\
n=55\end{array}$ & 94.5 & 74.5 & 32.7 \\
\hline \multirow[t]{2}{*}{ IMMvent [54] } & $\begin{array}{l}150 \mathrm{mg} \text { at } 0 \text { and } 4 \text { weeks, then every } 12 \text { weeks } \\
n=301\end{array}$ & 90.7 & 72.4 & 39.9 \\
\hline & $\begin{array}{l}\text { Comparator }{ }^{\text {b}}: \text { adalimumab } \\
n=304\end{array}$ & 71.7 & 47.4 & 23.0 \\
\hline \multirow[t]{2}{*}{ IMMhance [57] } & $\begin{array}{l}\text { Placebo } \\
n=100\end{array}$ & 8.0 & 2.0 & 1.0 \\
\hline & $\begin{array}{l}150 \mathrm{mg} \text { at } 0 \text { and } 4 \text { weeks, then every } 12 \text { weeks } \\
n=407\end{array}$ & 88.7 & 73.2 & 47.2 \\
\hline \multirow[t]{2}{*}{ IMMerge [55] } & $\begin{array}{l}150 \mathrm{mg} \text { at } 0 \text { and } 4 \text { weeks, then every } 12 \text { weeks } \\
n=164\end{array}$ & NA & 73.8 & NA \\
\hline & $\begin{array}{l}\text { Comparator }{ }^{\text {}}: \text { secukinumab } \\
n=163\end{array}$ & NA & 65.6 & NA \\
\hline \multicolumn{5}{|l|}{ Mirikizumab } \\
\hline \multirow[t]{4}{*}{ Reich et al. [58] } & $\begin{array}{l}\text { Placebo } \\
n=52\end{array}$ & 3.8 & 0.0 & 0.0 \\
\hline & $\begin{array}{l}30 \mathrm{mg} \text { at } 0 \text { and } 8 \text { weeks } \\
n=51\end{array}$ & 52.9 & 29.4 & 15.7 \\
\hline & $\begin{array}{l}100 \mathrm{mg} \text { at } 0 \text { and } 8 \text { weeks } \\
n=51\end{array}$ & 78.4 & 58.8 & 31.4 \\
\hline & $\begin{array}{l}300 \mathrm{mg} \text { at } 0 \text { and } 8 \text { weeks } \\
n=51\end{array}$ & 74.5 & 66.7 & 31.4 \\
\hline
\end{tabular}

NA not available

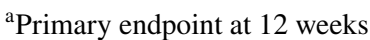

${ }^{\mathrm{b}}$ Comparator drug dosed per package insert: etanercept $50 \mathrm{mg}$ twice weekly; adalimumab $80 \mathrm{mg}$ at 0 weeks, then $40 \mathrm{mg}$ at $1 \mathrm{week}$ every 2 weeks; ustekinumab $45 \mathrm{mg}$ for patients weighing $\leq 100 \mathrm{~kg}$ at baseline or $90 \mathrm{mg}$ for patients weighing $>100 \mathrm{~kg}$; secukinumab $300 \mathrm{mg}$ at $0,1,2$, 3 , and 4 weeks, then every 4 weeks 
Table 4 Long-term Psoriasis Area Severity Index (PASI) results of interleukin-23 inhibitors in the overall population

\begin{tabular}{|c|c|c|c|c|}
\hline Study (years) & Dosing or cohort & PASI $75(\%)$ & PASI $90(\%)$ & PASI $100(\%)$ \\
\hline \multicolumn{5}{|l|}{ Ustekinumab } \\
\hline \multirow[t]{2}{*}{ PHOENIX 1 (5 years) [34] } & $\begin{array}{l}45 \mathrm{mg} \text { at } 0 \text { and } 4 \text { weeks, then every } 12 \text { weeks } \\
n=320\end{array}$ & 63.4 & 39.7 & 21.6 \\
\hline & $\begin{array}{l}90 \mathrm{mg} \text { at } 0 \text { and } 4 \text { weeks, then every } 12 \text { weeks } \\
n=296\end{array}$ & 72.0 & 49.0 & 26.4 \\
\hline \multirow[t]{2}{*}{ PHOENIX 2 (5 years) [33] } & $45 \mathrm{mg}$ at 0 and 4 weeks, then every 12 weeks $^{\mathrm{a}}$ & 76.5 & 50.0 & 28.1 \\
\hline & $90 \mathrm{mg}$ at 0 and 4 weeks, then every 12 weeks $^{\mathrm{a}}$ & 78.6 & 55.5 & 31.3 \\
\hline \multicolumn{5}{|l|}{ Guselkumab } \\
\hline VOYAGE 1 (4 years) [43] & $\begin{array}{l}100 \mathrm{mg} \text { at } 0 \text { and } 4 \text { weeks, then every } 8 \text { weeks } \\
n=411\end{array}$ & 93.4 & 82.2 & 55.7 \\
\hline VOYAGE 2 (4 years) [44] & $\begin{array}{l}100 \mathrm{mg} \text { at } 0 \text { and } 4 \text { weeks, then every } 8 \text { weeks } \\
n=596\end{array}$ & 92.3 & 79.7 & 51.0 \\
\hline \multicolumn{5}{|l|}{ Tildrakizumab } \\
\hline \multirow[t]{2}{*}{ reSURFACE 1 (3 years) [123] } & $\begin{array}{l}100 \mathrm{mg} \text { at } 0 \text { and } 4 \text { weeks, then every } 12 \text { weeks } \\
n=205\end{array}$ & 84.4 & 57.6 & 24.9 \\
\hline & $\begin{array}{l}200 \mathrm{mg} \text { at } 0 \text { and } 4 \text { weeks, then every } 12 \text { weeks } \\
n=248\end{array}$ & 75.4 & 50.8 & 25.4 \\
\hline \multirow[t]{2}{*}{ reSURFACE 2 (3 years) [124] } & $\begin{array}{l}100 \mathrm{mg} \text { at } 0 \text { and } 4 \text { weeks, then every } 12 \text { weeks } \\
n=320\end{array}$ & 89.1 & 64.4 & 35.3 \\
\hline & $\begin{array}{l}200 \mathrm{mg} \text { at } 0 \text { and } 4 \text { weeks, then every } 12 \text { weeks } \\
n=295\end{array}$ & 88.5 & 61.7 & 29.8 \\
\hline \multicolumn{5}{|l|}{ Risankizumab } \\
\hline IMMhance (2 years) [57] & $\begin{array}{l}150 \mathrm{mg} \text { at } 0 \text { and } 4 \text { weeks, then every } 12 \text { weeks } \\
n=111\end{array}$ & 91.0 & NA & NA \\
\hline
\end{tabular}

$N A$ not available

${ }^{\mathrm{a}}$ Unspecified $n$

study. PASI 90 was also significantly higher in ustekinumab vs etanercept [32]. Sustained use of ustekinumab has been found to have continued efficacy for at least 5 years $[33,34]$.

A trio of phase III placebo-controlled trials evaluated the efficacy of ustekinumab in patients in various Asian countries. The PEARL trial was assessed in 121 Taiwanese and Korean patients randomly assigned to placebo or ustekinumab. Igarashi et al. randomized 158 Japanese patients to placebo or ustekinumab. Finally, the LOTUS trial involved 322 Chinese patients receiving placebo or ustekinumab. All three trials achieved the primary endpoint of PASI 75 at week 12, with a range of 59-83\% [35-37].

The phase II trial of ustekinumab could not provide definitive conclusions about the risk profile of the drug but no unexpected findings were identified [29]. The most common adverse events reported from the PHOENIX and ACCEPT trials were upper respiratory tract infections, nasopharyngitis, arthralgia, headache, and injection-site erythema. These occurred at a similar rate between placebo and ustekinumab groups and were not dose dependent. Serious infections were rare and included cellulitis, herpes zoster, and diverticulitis [30-32]. Long-term follow-up of 5 years did not demonstrate any additional safety concerns with the overall risk profile remaining favorable. Pooled data from the phase II,
PHOENIX, and ACCEPT trials found a rate of 7.1 serious events per 100 patient-years [infections (1.1), malignancy (1.1), cardiac disorders (1.1)] [38].

\subsection{Guselkumab}

Guselkumab is a fully human, $\operatorname{IgG} 1 \lambda$ monoclonal antibody targeting the p19 subunit of IL-23 [39-41]. Dosing was evaluated in the phase II trial X-PLORE comprising 293 patients randomly assigned to adalimumab $(80 \mathrm{mg}$ at 0 weeks, $40 \mathrm{mg}$ at 1 week, then every 2 weeks) or guselkumab $(5,50$, or 200 $\mathrm{mg}$ at 0 and 4 weeks, then every 12 weeks or 15 or $100 \mathrm{mg}$ every 8 weeks; or 15 or 100 mg every 8 weeks). The primary endpoint was Physician Global Assessment score of 0 or 1 (PGA 0/1) at week 16 and achieved by all dosing groups compared with placebo [200 mg (83\%), $100 \mathrm{mg}(86 \%), 50$ $\mathrm{mg}$ (79\%), $15 \mathrm{mg}$ (61\%), $5 \mathrm{mg}(34 \%)$, and placebo (7\%)]. Similarly, all dosing groups attained a higher PASI 75, 90, and 100 than placebo. In addition, the proportion of Static Physician Global Assessment score of 0 or 1 (sPGA 0/1) was significantly higher in the 50-, 100-, and 200-mg dose groups than in the adalimumab group [40].

VOYAGE $1 / 2$ were the first phase III trials to study guselkumab in psoriasis treatment. In total, 1829 patients 
Table 5 Comparison of most frequent adverse events (AEs) at 16 weeks

\begin{tabular}{|c|c|c|c|c|c|}
\hline $\mathrm{AE}$ & $\begin{array}{l}\text { Ustekinumab, } n= \\
556 \text { [total number } \\
(\%)]^{\mathrm{a}}\end{array}$ & $\begin{array}{l}\text { Guselkumab, } n= \\
494 \text { [total number } \\
(\%) \text { ] }\end{array}$ & $\begin{array}{l}\text { Tildrakizumab, } n= \\
1238 \text { [total number } \\
(\%)]^{\mathrm{a}}\end{array}$ & $\begin{array}{l}\text { Risankizumab, } n= \\
598 \text { [total number } \\
(\%) \text { ] }\end{array}$ & $\begin{array}{l}\text { Mirikizumab, } n= \\
153 \text { [total number } \\
(\%) \text { ] }\end{array}$ \\
\hline Any AE & $378(68.0)$ & 235 (47.6) & $567(45.8)$ & $285(47.7)$ & $74(48.4)$ \\
\hline Serious AE & $8(1.4)$ & $8(1.6)$ & $23(1.9)$ & $13(2.2)$ & $2(1.3)$ \\
\hline Severe AE & NA & NA & NA & $13(2.2)$ & NA \\
\hline $\begin{array}{l}\text { AE leading to drug discon- } \\
\text { tinuation }\end{array}$ & $8(1.4)$ & $7(1.4)$ & $11(0.9)$ & $3(0.5)$ & NA \\
\hline Death & $2(0.4)$ & NA & $1(0.1)$ & $1(0.2)$ & $0(0)$ \\
\hline Nasopharyngitis & $55(9.9)$ & $35(7.1)$ & $120(9.7)$ & NA & \\
\hline Viral URI & NA & NA & NA & $30(5.0)$ & $19(12.4)$ \\
\hline URI & $35(6.3)$ & $16(3.2)$ & $25(2.0)$ & $28(4.7)$ & $11(7.2)$ \\
\hline Headache & $73(13.1)$ & $25(5.1)$ & NA & NA & NA \\
\hline Psoriasis & NA & NA & $3(0.2)$ & $0(0)$ & NA \\
\hline $\begin{array}{l}\text { Injection-site erythema/ } \\
\text { reaction }\end{array}$ & $22(4.0)$ & NA & $4(0.3)$ & NA & 7 (4.6) \\
\hline Diarrhea & NA & NA & NA & $6(1.0)$ & $4(2.6)$ \\
\hline Severe infection & $12(2.2)$ & $1(0.2)$ & $3(0.2)$ & $4(0.7)$ & NA \\
\hline Malignancy & $4(0.7)$ & $0(0)$ & $2(0.2)$ & $2(0.3)$ & NA \\
\hline Tuberculosis & NA & NA & NA & $0(0)$ & NA \\
\hline
\end{tabular}

URI upper respiratory tract infection, $N A$ not available

Ustekinumab data from ACCEPT [32]; guselkumab data from VOYAGE 2 [42]; tildrakizumab data from reSURFACE1 and 2 [50]; risankizumab data from UltIMMA-1 and -2 [53]; mirikizumab data from Reich et al. [58]

${ }^{a}$ Primary endpoint at 12 weeks

were randomized to receive placebo, adalimumab, or guselkumab at $100 \mathrm{mg}$ at 0 and 4 weeks, then every 8 weeks. The primary endpoint was compared to placebo and evaluated by an Investigator Global Assessment (IGA) score 0 or 1 at week 16 achieved by $84-85 \%$; PASI 90 was coprimary and achieved by $70-73 \%$. Guselkumab was also superior to adalimumab at these endpoints. In addition, guselkumab showed significant improvement in scalp, nail, and extremity disease as well as quality-of-life measures [41, 42]. For the VOYAGE trials, high efficacy rates were sustained for 4 years [43, 44].

Guselkumab was directly compared to the IL-17 inhibitor secukinumab in the ECLIPSE trial. The comparator-controlled trial randomized 1048 patients to secukinumab or guselkumab at $100 \mathrm{mg}$ at 0 and 4 weeks, then every 8 weeks. PASI 75 and 90 scores response rates were similar at 12 weeks, displaying short-term non-inferiority; however, the primary endpoint of PASI 90 at week 48 demonstrated superior long-term efficacy of guselkumab over secukinumab with $84 \%$ vs $70 \%$ (non-inferiority test $p<0.0001$, superiority test $p<0.0001)$ [45].

Ohtsuki et al. also investigated guselkumab in a phase III trial of Japanese patients with 192 patients receiving either placebo or guselkumab. The efficacy of guselkumab was confirmed in this trial with primary endpoints at week 16 of IGA 0/1 and PASI 90 achieved [46]. In the NAVIGATE trial, guselkumab also demonstrated potential as an alternative to ustekinumab treatment. Patients with inadequate response to ustekinumab, as defined by a failure to achieve IGA $0 / 1$ by week 16, showed significant improvement upon switching to guselkumab [47]. The ORION study evaluated the use of a novel convenient patient-controlled injector confirming comparable efficacy and safety with alternate administration. Importantly, patient questionnaires indicated high satisfaction rates with use of the device [48].

There was no evidence of dose dependence in the rate of adverse events in the guselkumab group from the weeks 0 to 16 in the X-PLORE trial. Furthermore, the patient proportions with one or more adverse events were $52 \%, 50 \%$, and $56 \%$ for the placebo group, guselkumab groups and adalimumab group, respectively. From weeks 16 to 52, three patients in the guselkumab group were observed to have major adverse cardiovascular events (MACE) compared to none in the adalimumab group [40]. Similar results were seen in the VOYAGE trials with the most common adverse events being nasopharyngitis, upper respiratory tract infection, injection-site erythema, headache, arthralgia, pruritus, and back pain [41, 42]. Guselkumab was confirmed to be well tolerated in subsequent phase III trials as well. Malignancy was rarely observed with the majority representing non-melanoma skin cancers. Serious infections were also occasionally seen, including skin abscesses, cellulitis, 
appendicitis; active tuberculosis (TB) was not identified [45, 46]. Long-term observation of guselkumab resulted in no unexpected safety findings after 4 years $[43,44]$.

\subsection{Tildrakizumab}

Tildrakizumab is a humanized IgG1 $\kappa$ monoclonal antibody that binds and inhibits the p19 subunit of IL-23 [49]. Dose ranging and efficacy of tildrakizumab was identified by Papp et al. in a phase II trial. Three hundred and fifty-five patients were randomly assigned to placebo or tildrakizumab dosed at $5,25,100$, or $200 \mathrm{mg}$ at 0 and 4 weeks, then every 12 weeks. The primary endpoint of PASI 75 was met by all dosing groups [200 mg (74.4\%), $100 \mathrm{mg}(66.3 \%), 25 \mathrm{mg}$ (64.4\%), $5 \mathrm{mg}$ (33.3\%), and placebo (4.4\%)]. sPGA 0/1 was also achieved by all groups and PASI 90 was achieved by all groups except for the 5-mg group. Patients in the 100and 200-mg groups sustained high levels of efficacy through week 52 and week 72 after discontinuation at week 52 [49].

A phase III study of tildrakizumab at 100- and 200-mg doses ensued in the reSURFACE trials. In reSURFACE 1, 772 patients were randomly assigned to placebo or tildrakizumab. Co-primary endpoints of PGA $0 / 1$ and PASI 75 were assessed at week 12 . PGA 0/1 was achieved by 58 and 59\% in the 100- and 200-mg groups and PASI 75 was achieved by 62 and $64 \%$ at 100 and $200 \mathrm{mg}$. In reSURFACE 2, 1090 patients were additionally randomized to an etanercept group. PGA 0/1 was met by 61 and $66 \%$ at 100 and 200 mg compared with $48 \%$ taking etanercept, while PASI 75 was met by 55 and $59 \%$ at 100 and $200 \mathrm{mg}$ compared with $48 \%$ taking etanercept [50]. Furthermore, PASI 75 and 90 responses were shown to be maintained through 3 years. In $60 \%$ of cases, partial responders at week 28 actually achieved PASI 75 by week 52 [51].

Tildrakizumab had a similar safety profile to guselkumab with nasopharyngitis, headache, and injection-site reaction representing the most common adverse events from the phase II study [49]. Serious adverse events occurred at similar frequencies across all tildrakizumab groups and were found to remain at a low incidence after nearly 3 years for those treated with tildrakizumab $[50,51]$.

\subsection{Risankizumab}

Risankizumab is a humanized IgG1 monoclonal antibody directed against the p19 subunit of IL-23 [52]. Papp et al. first investigated risankizumab in a phase II study involving 166 patients randomized to ustekinumab at standard doses or risankizumab at $18 \mathrm{mg}$ at 0 weeks or 90 or 180 $\mathrm{mg}$ at 0,4 , and 16 weeks. The primary endpoint, PASI 90, was achieved by the $90-$ and 180-mg groups with 73 and $81 \%$, respectively, compared with $40 \%$ in the ustekinumab group. In addition, risankizumab showed sustained and superior efficacy to ustekinumab in the treatment of scalp, fingernail, and palmoplantar disease [52].

These results were followed by the UltIMMA-1 and -2 phase III studies. In these trials, 997 total patients were randomly assigned to placebo, ustekinumab, or risankizumab at $150 \mathrm{mg}$ at 0 and 4 weeks, then every 12 weeks. Primary endpoints were assessed at week 16 by sPGA $0 / 1$ and PASI 90 . The sPGA endpoint was achieved by $84-88 \%$ on risankizumab compared with $62-63 \%$ on ustekinumab and PASI 90 was achieved by $75 \%$ compared to $42-48 \%$. The secondary endpoint, PASI 75, was attained by $89-91 \%$ compared to $70-76 \%$ on ustekinumab [53]. The phase III trial IMMvent subsequently compared the efficacy of risankizumab and the TNF- $\alpha$ inhibitor adalimumab. In this trial, 605 patients were randomly assigned to adalimumab or risankizumab (150 mg at 0 and 4 weeks, then every 12 weeks). Similarly, all primary and secondary endpoints were achieved. The sPGA $0 / 1$ and PASI 90 were attained by 84 and $72 \%$ of risankizumab-treated patients compared with 60 and $47 \%$ of adalimumab-treated patients, respectively [54].

Finally, the IMMerge phase III trial directly compared risankizumab $(150 \mathrm{mg}$ at 0 and 4 weeks, then every 12 weeks) with the IL-17 inhibitor secukinumab in 327 patients. The primary endpoint, PASI 90 at week 16, was achieved by $74 \%$ in the risankizumab group compared with $66 \%$ in the secukinumab group, demonstrating short-term non-inferiority. Furthermore, PASI 90 at week 52 was attained by $87 \%$ of risankizumab-treated patients vs $57 \%$ of secukinumabtreated patients, displaying superior long-term efficacy [55].

The SustaIMM study was a phase II/III trial conducted in 171 Japanese patients, confirming the efficacy of risankizumab ( 75 or $150 \mathrm{mg}$ at 0 and 4 weeks, then every 12 weeks) compared with placebo. All primary and secondary endpoints were met with PASI 90 at week 16 achieved by 75 and $76 \%$ at the 75 and $150 \mathrm{mg}$ doses of risankizumab [56]. The phase III, 2-year trial IMMhance further confirmed this with 507 patients randomly assigned to placebo or risankizumab at $150 \mathrm{mg}$ at 0 and 4 weeks, then every 12 weeks. The primary endpoints PASI 90 and sPGA 0/1 at week 16 were met by 73 and $84 \%$ vs 2 and $7 \%$. Notably, risankizumab response was sustained throughout the duration of the trial [57].

The most common adverse events seen in those taking risankizumab were nasopharyngitis, headache, gastroenteritis, and back pain [52]. Subsequent phase III trials also did not find any unexpected safety findings. Additional common adverse events that were reported include upper respiratory tract infections, diarrhea, and arthralgia. Overall, the frequency of serious events, including MACE, infection, and malignancy, was similar among all treatment groups and reflected baseline risks in patients with psoriasis. The IMMhance trial confirmed a favorable risk profile that was further maintained through the 2-year trial [57]. 


\subsection{Developmental}

Mirikizumab is a humanized IgG4 monoclonal antibody targeting the p19 subunit of IL-23 [58]. Mirikizumab was first evaluated in a 2019 phase II study comprising 205 patients. Treatment groups were divided into doses of 30,100 , or 300 $\mathrm{mg}$ given at 0 and 8 weeks, all of which displayed significant improvement in PASI 90 as compared with placebo. Both the 100- and 300-mg groups demonstrated higher PASI 90 compared with the 30-mg group, attaining 59 and $67 \%$, respectively. PASI 75 and 100 were also significantly higher with mirikizumab treatment compared with placebo [58].

A series of phase III trials are underway studying the efficacy and safety of mirikizumab in the treatment of psoriasis, including in the long term (OASIS-1/2/3; NCT03482011, NCT03535194, NCT03556202). Recently, Lilly announced early results of the OASIS-2 study, comparing mirikizumab with the IL-17 inhibitor secukinumab. The study randomly assigned 1465 patients to placebo, secukinumab (300 mg at $0,1,2,3$, and 4 weeks, then every 4 weeks), and mirikizumab ( $250 \mathrm{mg}$ at $0,4,8$, and 12 weeks, then every 8 weeks; or $250 \mathrm{mg}$ at $0,4,8$, and 12 weeks, then $125 \mathrm{mg}$ every 8 weeks). Preliminary results indicated non-inferiority at week 16 and superiority at week 52 of mirikizumab compared with secukinumab. PASI 90 at week 16 was achieved by $74.4 \%$ of mirikizumab-treated patients compared with $72.8 \%$ of secukinumab-treated patients. In addition, sPGA 0/1 was achieved by $79.7 \%$ in the mirikizumab group compared with $76.3 \%$ in the secukinumab group [59].

As yet, the safety profile of mirikizumab is similar to the other IL-23 inhibitors. The most common adverse events reported from Reich et al. and OASIS-2 were nasopharyngitis, upper respiratory tract infection, injection-site pain, hypertension, and diarrhea. Overall frequency of serious adverse events did not differ between treatment groups [58, 59]. Brazikumab is a human IgG2 monoclonal antibody targeting the p19 subunit of IL-23 that has been studied for use in Crohn's disease but has yet to be investigated in the treatment of psoriasis [60].

\section{Treatment of Psoriatic Arthritis}

Interleukin-23 inhibitors have also been studied in phase II and III trials of PsA (Table 6). Primary endpoints of these trials examined the American College of Rheumatology 20 (ACR20), which measures the proportion of patients with at least a $20 \%$ improvement from baseline. Secondary endpoints included ACR50 and ACR 70. The ACR score is assessed based on pain, physical functioning, and acutephase reactant levels. Inclusion criteria for the trials included active PsA (varied, but generally $\geq 3-5$ swollen joints, $\geq 3-5$ tender joints, and a threshold C-reactive protein level) and active psoriasis (target lesion $\geq 2 \mathrm{~cm}$ and inadequate response to therapy other than biologic drugs).

\subsection{Ustekinumab}

Ustekinumab was approved for the treatment of PsA in 2013. An initial phase II trial randomly assigned 146 patients to placebo or ustekinumab (17 patients received the $90-\mathrm{mg}$ dose, after which filtration procedure was implemented, resulting in remaining 59 patients to receive the $63-\mathrm{mg}$ dose). The primary endpoint of ACR 20 was assessed at week 12 achieved by $42 \%$ of patients receiving ustekinumab. Secondary endpoints of ACR50 and ACR70 at week 12 were achieved by 25 and $11 \%$ [61].

The PSUMMIT 1/2 phase III study followed with 927 total patients randomly assigned to placebo or ustekinumab at 45 or $90 \mathrm{mg}$ at 0 and 4 weeks, then every 12 weeks. At week 24, the primary endpoint of ACR20 was achieved by $42-44 \%$ at $45 \mathrm{mg}$ and $44-50 \%$ at $90 \mathrm{mg}$. Similarly, the ACR50 was achieved by $18-25 \%$ at $45 \mathrm{mg}$ and $23-28 \%$ at $90 \mathrm{mg}$ and the ACR70 was achieved by $7-12 \%$ at $45 \mathrm{mg}$ and $9-14 \%$ at $90 \mathrm{mg}$. Radiographic progression of disease was also significantly reduced through 52 weeks in the ustekinumab group $[62,63]$. The ECLIPSA trial directly compared ustekinumab with TNF- $\alpha$ inhibitors in treating enthesitis, demonstrating achievement of primary endpoint of clearance of enthesitis [64]. Ustekinumab was also assessed in axial spondyloarthritis in three trials, the latter two of which were discontinued after primary and secondary endpoints were not met in the first trial [65].

\subsection{Guselkumab}

Guselkumab was recently approved by the FDA as the first selective IL-23 inhibitor for the treatment of PsA [66]. Guselkumab first showed efficacy in a phase II study randomizing 149 patients to placebo or guselkumab at $100 \mathrm{mg}$ at 0 and 4 weeks, then every 8 weeks. The primary endpoint, ACR20 at week 24 , was achieved by $58 \%$ of patients receiving guselkumab compared with $18 \%$ of patients receiving placebo. The ACR50 and ACR70 secondary endpoints also demonstrated significant improvement of 34 and $14 \%$ in the guselkumab group compared with 10 and $2 \%$ in the placebo group. ACR20 and ACR50 were achieved as early as week 16 [67].

The DISCOVER-1/2 phase III studies involved 1122 total patients randomly assigned to guselkumab $(100 \mathrm{mg}$ at 0 and 4 weeks, then every 8 weeks; or $100 \mathrm{mg}$ every 4 weeks) or placebo. The primary endpoint of ACR20 at week 24 was achieved by 52 and $64 \%$ of guselkumabtreated patients in the trials compared with 22 and $23 \%$ of placebo-treated patients. Secondary endpoints, including ACR50 and ACR70 at week 24, were also achieved. 
Table 6 American College of Rheumatology results of interleukin-23 inhibitors at 24 weeks

\begin{tabular}{|c|c|c|c|c|}
\hline Study & Dosing or cohort & ACR20 (\%) & ACR50 (\%) & $\operatorname{ACR} 70(\%)$ \\
\hline \multicolumn{5}{|l|}{ Ustekinumab } \\
\hline \multirow[t]{2}{*}{ Gottlieb et al. ${ }^{\mathrm{a}}[61]$} & $\begin{array}{l}\text { Placebo } \\
n=70\end{array}$ & 14.3 & 7.1 & 0.0 \\
\hline & $\begin{array}{l}90 \mathrm{mg} \text { or } 63 \mathrm{mg} \text { at } 0,1,2, \text { and } 3 \text { weeks } \\
n=76\end{array}$ & 42.1 & 25.0 & 10.5 \\
\hline \multirow[t]{3}{*}{ PSUMMIT 1 [62] } & $\begin{array}{l}\text { Placebo } \\
n=206\end{array}$ & 22.8 & 8.7 & 2.4 \\
\hline & $\begin{array}{l}45 \mathrm{mg} \text { at } 0 \text { and } 4 \text { weeks, then every } 12 \text { weeks } \\
n=205\end{array}$ & 42.4 & 24.9 & 12.2 \\
\hline & $\begin{array}{l}90 \mathrm{mg} \text { at } 0 \text { and } 4 \text { weeks, then every } 12 \text { weeks } \\
n=204\end{array}$ & 49.5 & 27.9 & 14.2 \\
\hline \multirow[t]{3}{*}{ PSUMMIT 2 [63] } & $\begin{array}{l}\text { Placebo } \\
n=104\end{array}$ & 20.2 & 6.7 & 2.9 \\
\hline & $\begin{array}{l}45 \mathrm{mg} \text { at } 0 \text { and } 4 \text { weeks, then every } 12 \text { weeks } \\
n=103\end{array}$ & 43.7 & 17.5 & 6.8 \\
\hline & $\begin{array}{l}90 \mathrm{mg} \text { at } 0 \text { and } 4 \text { weeks, then every } 12 \text { weeks } \\
n=105\end{array}$ & 43.8 & 22.9 & 8.6 \\
\hline \multicolumn{5}{|l|}{ Guselkumab } \\
\hline \multirow[t]{2}{*}{ Deodhar et al. [67] } & $\begin{array}{l}\text { Placebo } \\
n=49\end{array}$ & 18.4 & 10.2 & 2.0 \\
\hline & $\begin{array}{l}100 \mathrm{mg} \text { at } 0 \text { and } 4 \text { weeks, then every } 8 \text { weeks } \\
n=100\end{array}$ & 58.0 & 34.0 & 14.0 \\
\hline \multirow[t]{3}{*}{ DISCOVER-1 [68] } & $\begin{array}{l}\text { Placebo } \\
n=126\end{array}$ & 22.2 & 8.7 & 5.6 \\
\hline & $\begin{array}{l}100 \mathrm{mg} \text { every } 4 \text { weeks } \\
n=128\end{array}$ & 59.4 & 35.9 & 20.3 \\
\hline & $\begin{array}{l}100 \mathrm{mg} \text { at } 0 \text { and } 4 \text { weeks, then every } 8 \text { weeks } \\
n=127\end{array}$ & 52.0 & 29.9 & 11.8 \\
\hline \multirow[t]{3}{*}{ DISCOVER-2 [69] } & $\begin{array}{l}\text { Placebo } \\
n=246\end{array}$ & 32.9 & 14.2 & 4.1 \\
\hline & $\begin{array}{l}100 \mathrm{mg} \text { every } 4 \text { weeks } \\
n=245\end{array}$ & 63.7 & 33.1 & 13.1 \\
\hline & $\begin{array}{l}100 \mathrm{mg} \text { at } 0 \text { and } 4 \text { weeks, then every } 8 \text { weeks } \\
n=248\end{array}$ & 64.1 & 31.5 & 18.5 \\
\hline
\end{tabular}

${ }^{\text {a Primary endpoint at } 12 \text { weeks }}$

${ }^{\mathrm{b}} 17 / 76$ patients received $90 \mathrm{mg}$; remaining patients received a filtered dose equivalent to $63 \mathrm{mg}$

In addition, guselkumab was significantly beneficial for improving physical functioning, enthesitis, dactylitis, and fatigue [68, 69]. Pooled analysis of the DISCOVER trials found resolution of enthesitis by $45-50 \%$ of the guselkumab group compared with $29 \%$ of placebo and resolution of dactylitis by 59-64\% of the guselkumab group compared with $42 \%$ of placebo; baseline scores were also significantly decreased after 24 weeks of treatment [69]. Similar efficacy in dactylitis and enthesitis was seen through 56 weeks in a phase II trial of patients with active PsA despite current or previous conventional therapy [70].

\subsection{Developmental}

Tildrakizumab and risankizumab remain in the trial phase for evaluation of their efficacy in PsA. Initial subset analyses of 65 patients with PsA in a phase II trial of tildrakizumab in the treatment of psoriasis showed an improved, but not necessarily statistically significant, change in ACR components and PsA endpoints such as the Psoriatic Arthritis Screening and Evaluation, Health Assessment Questionnaire, pain assessed with the Visual Analog Scale, and high-sensitivity C-reactive protein (NCT01225731) [71]. A recent case 
report in Australia described a patient with improvement of PsA within 9 weeks after subcutaneous administration at 0 and 4 weeks [72]. A phase IIb trial randomized 391 patients to receive tildrakizumab (200 mg every 4 weeks, $200 \mathrm{mg}$ every 12 weeks, $100 \mathrm{mg}$ every 12 weeks, or $20 \mathrm{mg}$ every 12 weeks) or placebo. Preliminary results showed clear efficacy of tildrakizumab in the treatment of PsA as compared to placebo with differences detected in ACR20 and ACR50 at 12 weeks in the 200-mg dose groups (NCT02980692) [73].

Risankizumab has been evaluated in a phase II trial with 185 patients randomized to risankizumab (150 mg every 4 weeks; $150 \mathrm{mg}$ at 0 and 4 weeks, then every 12 weeks; $150 \mathrm{mg}$ every 12 weeks; or $75 \mathrm{mg}$ at 0 weeks) or placebo. Preliminary results demonstrated superior ACR20, ACR50, and ACR70 scores in all risankizumab dosage groups as compared with placebo (NCT02719171) [74]. Meanwhile, a phase III trial series is currently underway to compare risankizumab with placebo in the treatment of PsA (KEEPsAKE1/2; NCT03671148). Risankizumab was also assessed for efficacy in ankylosing spondylitis, but similar to ustekinumab failed to meet the primary endpoint [75].

\section{Discussion}

Interleukin-23 inhibitors represent safe and effective options in the treatment of patients with psoriasis and psoriatic arthritis. As reflected by their primary endpoints, clinical trials demonstrate the superior efficacy of IL-23 inhibitors to traditional forms of therapy, including TNF- $\alpha$ inhibitors. Guselkumab and risankizumab may particularly stand out (Fig. 1); however, comparison of efficacy among the IL-23 inhibitors has been mixed. Sawyer et al. performed a network meta-analysis that showed guselkumab and risankizumab were superior to tildrakizumab [76]. In contrast, Du Jardin et al. performed an indirect comparison of guselkumab and tildrakizumab and found no significant difference in efficacy at short-term time points [77]; of note, their analysis did not include phase II trials. The investigators of the reSURFACE trials noted that the 12-week primary endpoint (two doses) may have been too early for adequate evaluation of tildrakizumab compared to the 16-week endpoint (three doses) for the other two drugs [50]. A study by AbbVie showed that guselkumab and risankizumab are high-affinity antibodies acting by competitive inhibition, whereas tildrakizumab is a negative allosteric modulator with high off-rates; as a result, risankizumab was found to have a three-fold higher potency compared with guselkumab and a 50-fold higher potency compared with tildrakizumab [78]. As more long-term data become available, more head-to-head comparisons will be necessary.

The IL-23 inhibitors have also been shown to lead to a long duration of remission after withdrawal of the drug. In trials of TNF- $\alpha$ inhibitors, the median time to loss of PASI 50 had a range of 12.1-19.5 weeks after discontinuation of therapy [79]. In contrast, median time to loss of PASI 50 in the PHOENIX 1 trial for ustekinumab was estimated to be about 22 weeks from the last dose [30, 79]. In the VOYAGE 2 trial, 182 out of 375 patients were randomized to guselkumab withdrawal with a median time to loss of PASI 90 at 23 weeks after the last dose [42]. The median time to loss of PASI 90 in the reSURFACE 2 trial was 28 and 32 weeks after the last dose of tildrakizumab 100 and $200 \mathrm{mg}$ [80]. Finally, the median time loss of PASI 90 was 42 weeks after the last dose with risankizumab in the IMMhance trial [57]. While response remains superior with maintenance of therapy, IL-23 inhibitors show a sustained level of efficacy even after discontinuation for several months.
Fig. 1 Comparison of best Psoriasis Area and Severity Index (PASI) 75/90/100 responses from phase III results. Ustekinumab data from ACCEPT trial [32]; guselkumab data from VOYAGE 1 [41]; tildrakizumab data from Papp et al. and reSURFACE 1 [49, 50]; risankizumab data from Papp et al. and UltIMMa-1 [52, 53]. LOTUS and ORION trial results were not compared because of differences in baseline data and treatment administration

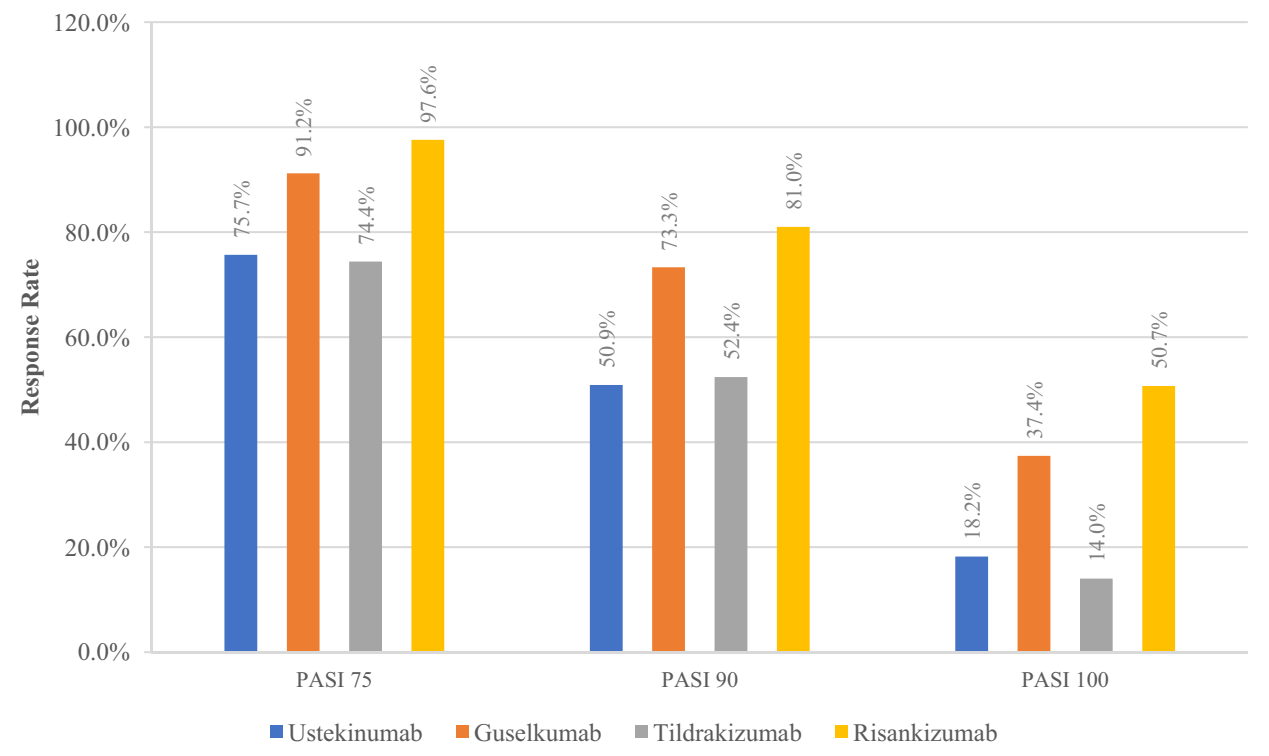


Similarly, selective targeting of IL-23 results in strong improvement of PsA. ACR20 and ACR50 response rates were significantly higher in studies of ustekinumab and guselkumab compared with placebo with promising preliminary results in tildrakizumab and risankizumab. Further studies evaluating the effectiveness of IL-23 inhibitors against other classes are needed, as anti-IL-23 therapy represents a fourth-line option behind treatments with better evidence. The 2018 ACR/National Psoriasis Foundation guidelines support the first-line use of TNF- $\alpha$ inhibitors in new active PsA, followed by oral small molecules, such as methotrexate or sulfasalazine, IL-17 inhibitors, and finally IL-12/IL-23 inhibitors (specific IL-23 inhibitors were not FDA approved yet) [81]. Some variations exist depending on contraindications or comorbidities, such as using IL-17 and IL-23 inhibitors in patients with concomitant severe psoriasis. As more data become available on the efficacy of IL-23 inhibitors, they may be used more in PsA treatment.

Targeting of IL-23 has emerged with an improved understanding of the role of the IL-23/Th17 axis in the development of psoriasis. Early investigation of skin samples from patients with psoriasis showed increased expression levels of IL-23 [20, 82]. Further studies elucidated the role of IL-23 activation of Th17 and subsequent production of pro-inflammatory cytokines including IL-17, TNF- $\alpha$, IL-26, and IL-29 that contribute to epidermal hyperplasia and recruitment of immune cells [83]. Interleukin-23 inhibition was first shown to be effective by Sofen et al. demonstrating histopathological improvement with a reduction in levels of IL-17 [39]. The efficacy of IL-23 blockade was further supported by reduction in IL-17 and IL-22 levels through the sequestration of IL-23 by a decoy protein containing the IL-23 receptor cytokine-binding homology region [84]. Such evidence provides support for potential development of an IL-23 receptor-Fc fusion protein, similar to etanercept [85].

A major advantage of IL-23 inhibitors is that targeting of upstream cytokines requires less frequent dosing compared with targeting of downstream cytokines such as IL-17 and TNF- $\alpha$ [86]. In addition, studies of IL-23 and IL-17 inhibitors to this point have shown sustained strong efficacy at 1 year and beyond [43, 44, 48, 87, 88]. A network metaanalysis of PASI response demonstrated that the short-term efficacy of IL-17 inhibitors, particularly ixekizumab and brodalumab, and IL-23 inhibitors, particularly guselkumab and risankizumab, were similar [76]. However, IL-17 inhibitors are superior in achieving a more rapid response, as seen in a head-to-head trial of ixekizumab and guselkumab [89]. As more long-term data become available, comparison of efficacy will be needed for further assessment. In the meantime, selection of these drugs should involve a discussion of patient preferences for care.

Notably, specific inhibition of IL-23 shows evidence of superiority compared with the anti-IL-12/23 action of ustekinumab. The phase II trial conducted by Papp et al. and the phase III trial UltIMMa-1/2 both demonstrated improved efficacy of risankizumab compared with ustekinumab [52, 53]. Preservation of IL-12 activation of T helper 1 response is thought to allow for interferon- $\gamma$ protection against intracellular pathogens, such as Mycobacterium species, Salmonella, Pneumocystis jirovecii, and Toxoplasmosis gondii [90, 91]. Further, IL-12 is unlikely to have a significant role in the pathogenesis of psoriasis [20]. However, UltIMMa-1/2 reported similar rates of adverse events including infections between ustekinumab and risankizumab treatment. The benefit of risankizumab over ustekinumab may not be completely attributed to improved pathogenic immunity and further comparison studies would be useful.

Safety profiles of IL-23 inhibitors to this point appear to be relatively benign with all classes most commonly possessing adverse events including nasopharyngitis, upper respiratory tract infection, headache, and backache. Most serious adverse events, including serious infection, MACE, malignancy, and death, that were observed in the clinical trials were in line with the expected proportions observed in the general population of patients with psoriasis. In many cases, patients already had pre-existing risk factors that predisposed them to the development of adverse events [92]. Drug-interaction studies conducted on these drugs have shown little to no effect on cytochrome P450 enzymes, further supporting a positive safety profile [93-96]. Given the novelty of these drugs, long-term studies to carefully monitor for the development of more serious side effects are naturally required. Of note is the risk of serious infection and reactivation of diseases such as TB in light of immune system modulation, as seen in TNF- $\alpha$ inhibitors [97]. However, IL-23 inhibitors were not shown to increase the risk for TB infection or reactivation. A recent review of IL-17 inhibitors also showed no cases of TB reactivation in patients with psoriasis treated with an IL-17 inhibitor [98]. It has been posited that IL-23 and IL-17 do not necessarily protect against TB, but they may be more involved in regulating inflammation in this setting [99]. However, routine annual monitoring for a potential TB infection is still recommended. In addition, multiple studies demonstrated that co-therapy with isoniazid to treat for latent TB did not change the efficacy or safety of IL-23 therapy $[100,101]$.

While the ustekinumab trials have not shown significantly more cardiovascular events compared to placebo, the association of IL-12/23 inhibitors and such events has remained controversial [102-104]. In particular, briakinumab was another IL-12/23 inhibitor that was withdrawn from FDA application after a phase III trial showed a significantly increased risk of MACE [105]. Despite the lack of conclusive data describing the risk of ustekinumab, patient discussion about risk factors and avoidance of the drug has been favored [106]. More recently, a French 
retrospective case-time-control study compared the risk of acute coronary syndrome or stroke in the 6 months before and after initiation of ustekinumab. The study found an increased risk for these events in patients considered high cardiovascular risk (two risk factors or personal history of acute coronary syndrome or stroke), positing a role for IL-17 in stabilizing atherosclerotic plaques [107]. In consideration of the latest study, mindful evaluation of risk factors such as hypertension, hyperlipidemia, and diabetes mellitus is important and alternatives to ustekinumab should be identified in high-risk patients.

The outbreak of Coronavirus Disease 2019 (COVID-19) has raised additional questions about the use of biologic drugs during a pandemic. Based on trial data, Lebwohl et al. found slight absolute increases, up to $9 \%$, in overall infection risk with IL-23 inhibition, but these cannot necessarily be extrapolated to COVID-19 risk [108]. Furthermore, the immune response to viral infections is known to involve multiple mediators in the innate and adaptive immune systems. As IL-23 does not represent a significant factor in this response, viral clearance may not be significantly impaired by targeted therapy. Patients should be counseled on the possibility of an increased risk of
COVID-19 infection and most may be able to continue therapy in the absence of severe symptoms [109].

While IL-17 inhibition is thought to be linked to new or exacerbated inflammatory bowel disease, IL-23 targeting is not associated with such a risk profile. In fact, IL-23 inhibitors are being investigated with promising efficacy to treat inflammatory bowel disease, and ustekinumab is already FDA approved to treat Crohn's disease [110, 111]. Similarly, IL-17 is key for immunity against Candida infection and rarely reported with targeting of IL-17, but not IL-23 [112].

The risks of treating psoriasis with biologic drugs in patients with underlying conditions require careful attention (Tables 7,8). While limited data exist overall on the safety and efficacy on IL-23 inhibitors in these populations, similar caution may be taken in the initiation of these drugs as with TNF- $\alpha$ inhibitors. According to the joint American Academy of Dermatology-National Psoriasis Foundation guidelines for the management and treatment of psoriasis with biologic drugs, baseline laboratory studies prior to initiating IL-23 inhibitor therapy include complete blood count, complete metabolic profile, TB test (PPD or Quantiferon Gold), hepatitis B virus and hepatitis C virus serology, and human immunodeficiency virus test. In addition, periodic testing for TB, hepatitis B virus, hepatitis C virus, other

Table 7 Considerations in special populations

\begin{tabular}{lllll}
\hline Drug & Pregnancy category & Lactating & Pediatric & Geriatric \\
\hline Ustekinumab & B & Insufficient data & $\begin{array}{c}\text { Approved in patients } \\
\text { aged } \geq 6 \text { years }\end{array}$ & No differences observed in limited data \\
Guselkumab & Insufficient data & Insufficient data & Insufficient data & No differences observed in limited data \\
Tildrakizumab & Insufficient data & Insufficient data & Insufficient data & No differences observed in limited data \\
Risankizumab & Insufficient data & Insufficient data & Insufficient data & No differences observed in limited data \\
\hline
\end{tabular}

Information from package inserts unless referenced otherwise [119-122]

Table 8 Considerations in infections and malignancy

\begin{tabular}{|c|c|c|c|c|c|}
\hline Drug & HIV & HBV & $\mathrm{HCV}$ & TB & Underlying malignancy \\
\hline Ustekinumab & $\begin{array}{l}\text { Safe and effective in } \\
\text { limited data; combine } \\
\text { with ART and monitor } \\
\text { closely }[98,99]\end{array}$ & Assess HBV serology & Assess HCV status & $\begin{array}{l}\text { Assess TB status; avoid } \\
\text { in active TB; treat } \\
\text { latent TB first }\end{array}$ & Screening for skin cancer \\
\hline Guselkumab & $\begin{array}{l}\text { Safe and effective in } 1 \\
\text { case; monitor closely } \\
\text { and consider ART [98] }\end{array}$ & $\begin{array}{l}\text { Assess HBV serology; } \\
\text { safe and effective in } 1 \\
\text { case [104] }\end{array}$ & Assess HCV status & $\begin{array}{l}\text { Assess TB status; avoid } \\
\text { in active TB; treat } \\
\text { latent TB first }\end{array}$ & Screening for skin cancer \\
\hline Tildrakizumab & Insufficient data & Assess HBV serology & Assess HCV status & $\begin{array}{l}\text { Assess TB status; avoid } \\
\text { in active TB; treat } \\
\text { latent TB first }\end{array}$ & Screening for skin cancer \\
\hline Risankizumab & Insufficient data & Assess HBV serology & Assess HCV status & $\begin{array}{l}\text { Assess TB status; avoid } \\
\text { in active TB; treat } \\
\text { latent TB first }\end{array}$ & Screening for skin cancer \\
\hline
\end{tabular}

$A R T$ anti-retroviral therapy, $H B V$ hepatitis B virus, $H C V$ hepatitis $\mathrm{C}$ virus, $H I V$ human immunodeficiency virus, $T B$ tuberculosis

Information from package inserts unless referenced otherwise [119-122] 
infections, and skin cancer should be implemented with variable frequency depending on individual patient risks [113]. It is recommended to treat patients for active or latent $\mathrm{TB}$ prior to the onset of therapy. Limited data show that ustekinumab treatment in patients with active or latent hepatitis $B$ virus or hepatitis $C$ virus is safe and effective and is not associated with an increased rate of reactivation [114-116]. In patients with human immunodeficiency virus, no differences in efficacy have been observed in a few cases of ustekinumab treatment and one case of guselkumab treatment; no data exist for tildrakizumab and risankizumab treatment $[117,118]$. The data in pregnant and lactating patients are limited and no FDA pregnancy category has been assigned to these drugs.

\section{Conclusions}

The wealth of research on the pathogenesis of psoriasis has unlocked new classes of drugs that redefine how psoriasis and PsA are treated. As the role of the IL-23/Th17 axis has become further uncovered, targeted therapy of IL-23 has rapidly risen to the forefront to set a new standard for psoriasis outcomes. Over the last 3 years, guselkumab, tildrakizumab, and risankizumab have successively come to the market, showing superior efficacy and favorable safety profiles compared to existing medications.

\section{Declarations}

Funding No funding was received for the preparation of this article.

Conflict of interest Boni E. Elewski receives research funding from Abbvie, AnaptysBio, Boehringer Ingelheim, Bristol Myers Squibb (BMS), Celgene, Incyte, Leo, Lilly, Merck, Menlo, Novartis, Pfizer, Regeneron, Janssen, Sun Pharma, Valeant (Ortho Dermatology), and Vanda. Boni E. Elewski receives honoraria from Arcutis, Boehringer Ingelheim, BMS, Celgene, Leo, Lilly, Menlo, Novartis, Pfizer, Sun Pharma, UCB, Valeant (Ortho Dermatology), and Verrica. Kevin Yang and Allen S.W. Oak have no conflicts of interest that are directly relevant to the content of this article.

Ethics approval Not applicable.

Consent to participate Not applicable.

Consent for publication Not applicable.

Availability of data and material All data and material are included in the article.

Code availability Not applicable.

Author contributions BEE and ASO conceptualized and designed the study. KY gathered data for the manuscript, and wrote the initial draft of the manuscript. All authors read and approved the final manuscript.

\section{References}

1. Rachakonda TD, Schupp CW, Armstrong AW. Psoriasis prevalence among adults in the United States. J Am Acad Dermatol. 2014;70(3):512-6. https://doi.org/10.1016/j.jaad.2013.11.013.

2. Brezinski EA, Dhillon JS, Armstrong AW. Economic burden of psoriasis in the United States: a systematic review. JAMA Dermatol. 2015;151(6):651-8. https://doi.org/10.1001/jamad ermatol.2014.3593.

3. Nestle FO, Kaplan DH, Barker J. Psoriasis. N Engl J Med. 2009;361(5):496-509. https://doi.org/10.1056/NEJMra0804 595.

4. Rendon A, Schäkel K. Psoriasis pathogenesis and treatment. Int J Mol Sci. 2019;20(6):1475. https://doi.org/10.3390/ijms2 0061475 .

5. Elmets CA, Leonardi CL, Davis DMR, Gelfand JM, Lichten J, Mehta NN, et al. Joint AAD-NPF guidelines of care for the management and treatment of psoriasis with awareness and attention to comorbidities. J Am Acad Dermatol. 2019;80(4):1073-113. https://doi.org/10.1016/j.jaad.2018.11.058.

6. Mease PJ, Gladman DD, Papp KA, Khraishi MM, Thaçi D, Behrens F, et al. Prevalence of rheumatologist-diagnosed psoriatic arthritis in patients with psoriasis in European/North American dermatology clinics. J Am Acad Dermatol. 2013;69(5):729-35. https://doi.org/10.1016/j.jaad.2013.07.023.

7. Ritchlin CT, Colbert RA, Gladman DD. Psoriatic arthritis. N Engl J Med. 2017;376(10):957-70. https://doi.org/10.1056/ NEJMra1505557.

8. Bos JD, Hulsebosch HJ, Krieg SR, Bakker PM, Cormane RH. Immunocompetent cells in psoriasis. In situ immunophenotyping by monoclonal antibodies. Arch Dermatol Res. 1983;275(3):181-9. https://doi.org/10.1007/bf00510050.

9. Baker BS, Swain AF, Fry L, Valdimarsson H. Epidermal $\mathrm{T}$ lymphocytes and HLA-DR expression in psoriasis. Br J Dermatol. 1984;110(5):555-64. https://doi. org/10.1111/j.1365-2133.1984.tb04678.x.

10. Austin LM, Ozawa M, Kikuchi T, Walters IB, Krueger JG. The majority of epidermal T cells in Psoriasis vulgaris lesions can produce type 1 cytokines, interferon-gamma, interleukin-2, and tumor necrosis factor-alpha, defining TC1 (cytotoxic T lymphocyte) and TH1 effector populations: a type 1 differentiation bias is also measured in circulating blood T cells in psoriatic patients. J Investig Dermatol. 1999;113(5):752-9. https://doi. org/10.1046/j.1523-1747.1999.00749.x.

11. Nestle FO, Turka LA, Nickoloff BJ. Characterization of dermal dendritic cells in psoriasis: autostimulation of T lymphocytes and induction of Th1 type cytokines. J Clin Investig. 1994;94(1):202-9. https://doi.org/10.1172/jci117308.

12. Detmar M, Orfanos CE. Tumor necrosis factor-alpha inhibits cell proliferation and induces class II antigens and cell adhesion molecules in cultured normal human keratinocytes in vitro. Arch Dermatol Res. 1990;282(4):238-45. https://doi. org/10.1007/bf00371643.

13. Harrington LE, Hatton RD, Mangan PR, Turner H, Murphy TL, Murphy KM, et al. Interleukin 17-producing CD4+ effector $\mathrm{T}$ cells develop via a lineage distinct from the $\mathrm{T}$ helper type 1 and 2 lineages. Nat Immunol. 2005;6(11):1123-32. https:// doi.org/10.1038/ni1254.

14. Chiricozzi A, Suárez-Fariñas M, Fuentes-Duculan J, Cueto I, Li K, Tian S, et al. Increased expression of interleukin-17 pathway genes in nonlesional skin of moderate-to-severe psoriasis vulgaris. Br J Dermatol. 2016;174(1):136-45. https:// doi.org/10.1111/bjd.14034.

15. Rizzo HL, Kagami S, Phillips KG, Kurtz SE, Jacques SL, Blauvelt A. IL-23-mediated psoriasis-like epidermal hyperplasia 
is dependent on IL-17A. J Immunol. 2011;186(3):1495-502. https://doi.org/10.4049/jimmunol.1001001.

16. Nograles KE, Zaba LC, Guttman-Yassky E, Fuentes-Duculan J, Suárez-Fariñas M, Cardinale I, et al. Th17 cytokines interleukin (IL)-17 and IL-22 modulate distinct inflammatory and keratinocyte-response pathways. Br J Dermatol. 2008;159(5):1092-102. https://doi.org/10.111 1/j.1365-2133.2008.08769.x.

17. Chiricozzi A, Guttman-Yassky E, Suárez-Fariñas M, Nograles KE, Tian S, Cardinale I, et al. Integrative responses to IL-17 and TNF- $\alpha$ in human keratinocytes account for key inflammatory pathogenic circuits in psoriasis. J Investig Dermatol. 2011;131(3):677-87. https://doi.org/10.1038/jid.2010.340.

18. Harper EG, Guo C, Rizzo H, Lillis JV, Kurtz SE, Skorcheva I, et al. Th17 cytokines stimulate CCL20 expression in keratinocytes in vitro and in vivo: implications for psoriasis pathogenesis. J Investig Dermatol. 2009;129(9):2175-83. https://doi. org/10.1038/jid.2009.65.

19. Liu Y, Lagowski JP, Gao S, Raymond JH, White CR, KuleszMartin MF. Regulation of the psoriatic chemokine CCL20 by E3 ligases Trim 32 and Piasy in keratinocytes. J Investig Dermatol. 2010;130(5):1384-90. https://doi.org/10.1038/jid.2009.416.

20. Lee E, Trepicchio WL, Oestreicher JL, Pittman D, Wang F, Chamian F, et al. Increased expression of interleukin 23 p19 and p40 in lesional skin of patients with psoriasis vulgaris. J Exp Med. 2004;199(1):125-30. https://doi.org/10.1084/jem.20030451.

21. Yawalkar N, Tscharner GG, Hunger RE, Hassan AS. Increased expression of IL-12p70 and IL-23 by multiple dendritic cell and macrophage subsets in plaque psoriasis. J Dermatol Sci. 2009;54(2):99-105. https://doi.org/10.1016/j.jderm sci.2009.01.003.

22. Cheng JB, Sedgewick AJ, Finnegan AI, Harirchian P, Lee $\mathrm{J}$, Kwon S, et al. Transcriptional programming of normal and inflamed human epidermis at single-cell resolution. Cell Rep. 2018;25(4):871-83. https://doi.org/10.1016/j.celre p.2018.09.006

23. Dolcino M, Ottria A, Barbieri A, Patuzzo G, Tinazzi E, Argentino $\mathrm{G}$, et al. Gene expression profiling in peripheral blood cells and synovial membranes of patients with psoriatic arthritis. PLoS ONE. 2015;10(6):e0128262. https://doi.org/10.1371/journ al.pone. 0128262

24. Xu X, Davelaar N, Mus AM, Asmawidjaja PS, Hazes JMW, Baeten DLP, et al. IL-17A is produced by synovial fluid CD4+ but not CD8+ T cells after TCR activation and regulates different inflammatory mediators compared to TNF in a synovitis model of psoriatic arthritis. Arthritis Rheumatol. 2020;72(8):1303-13. https://doi.org/10.1002/art.41271.

25. Chen L, Deshpande M, Grisotto M, Smaldini P, Garcia R, He Z, et al. Skin expression of IL-23 drives the development of psoriasis and psoriatic arthritis in mice. Sci Rep. 2020;10(1):8259. https://doi.org/10.1038/s41598-020-65269-6.

26. Yang L, Fanok MH, Mediero-Munoz A, Fogli LK, Corciulo C, Abdollahi S, et al. Augmented Th17 differentiation leads to cutaneous and synovio-entheseal inflammation in a novel model of psoriatic arthritis. Arthritis Rheumatol. 2018;70(6):855-67. https ://doi.org/10.1002/art.40447.

27. Kim KW, Kim HR, Park JY, Park JS, Oh HJ, Woo YJ, et al. Interleukin-22 promotes osteoclastogenesis in rheumatoid arthritis through induction of RANKL in human synovial fibroblasts. Arthritis Rheum. 2012;64(4):1015-23. https://doi.org/10.1002/ art.33446.

28. El-Zayadi AA, Jones EA, Churchman SM, Baboolal TG, Cuthbert RJ, El-Jawhari JJ, et al. Interleukin-22 drives the proliferation, migration and osteogenic differentiation of mesenchymal stem cells: a novel cytokine that could contribute to new bone formation in spondyloarthropathies. Rheumatology (Oxford).
2017;56(3):488-93. https://doi.org/10.1093/rheumatology/ kew384.

29. Krueger GG, Langley RG, Leonardi C, Yeilding N, Guzzo C, Wang Y, et al. A human interleukin-12/23 monoclonal antibody for the treatment of psoriasis. N Engl J Med. 2007;356(6):58092. https://doi.org/10.1056/NEJMoa062382.

30. Leonardi CL, Kimball AB, Papp KA, Yeilding N, Guzzo C, Wang Y, et al. Efficacy and safety of ustekinumab, a human interleukin-12/23 monoclonal antibody, in patients with psoriasis: 76-week results from a randomised, double-blind, placebocontrolled trial (PHOENIX 1). Lancet. 2008;371(9625):1665-74. https://doi.org/10.1016/s0140-6736(08)60725-4.

31. Papp KA, Langley RG, Lebwohl M, Krueger GG, Szapary P, Yeilding N, et al. Efficacy and safety of ustekinumab, a human interleukin-12/23 monoclonal antibody, in patients with psoriasis: 52-week results from a randomised, double-blind, placebocontrolled trial (PHOENIX 2). Lancet. 2008;371(9625):1675-84. https://doi.org/10.1016/s0140-6736(08)60726-6.

32. Griffiths CE, Strober BE, van de Kerkhof P, Ho V, FidelusGort R, Yeilding N, et al. Comparison of ustekinumab and etanercept for moderate-to-severe psoriasis. N Engl J Med. 2010;362(2):118-28. https://doi.org/10.1056/NEJMoa0810652.

33. Langley RG, Lebwohl M, Krueger GG, Szapary PO, Wasfi Y, Chan D, et al. Long-term efficacy and safety of ustekinumab, with and without dosing adjustment, in patients with moderateto-severe psoriasis: results from the PHOENIX 2 study through 5 years of follow-up. Br J Dermatol. 2015;172(5):1371-83. https ://doi.org/10.1111/bjd.13469.

34. Kimball AB, Papp KA, Wasfi Y, Chan D, Bissonnette R, Sofen H, et al. Long-term efficacy of ustekinumab in patients with moderate-to-severe psoriasis treated for up to 5 years in the PHOENIX 1 study. J Eur Acad Dermatol Venereol. 2013;27(12):1535-45. https://doi.org/10.1111/jdv.12046.

35. Tsai TF, Ho JC, Song M, Szapary P, Guzzo C, Shen YK, et al. Efficacy and safety of ustekinumab for the treatment of moderateto-severe psoriasis: a phase III, randomized, placebo-controlled trial in Taiwanese and Korean patients (PEARL). J Dermatol Sci. 2011;63(3):154-63. https://doi.org/10.1016/j.jderm sci.2011.05.005.

36. Igarashi A, Kato T, Kato M, Song M, Nakagawa H. Efficacy and safety of ustekinumab in Japanese patients with moderate-tosevere plaque-type psoriasis: long-term results from a phase $2 / 3$ clinical trial. J Dermatol. 2012;39(3):242-52. https://doi.org/10 .1111/j.1346-8138.2011.01347.x.

37. Zhu X, Zheng M, Song M, Shen YK, Chan D, Szapary PO, et al. Efficacy and safety of ustekinumab in Chinese patients with moderate to severe plaque-type psoriasis: results from a phase 3 clinical trial (LOTUS). J Drugs Dermatol. 2013;12(2):166-74.

38. Papp KA, Griffiths CE, Gordon K, Lebwohl M, Szapary PO, Wasfi Y, et al. Long-term safety of ustekinumab in patients with moderate-to-severe psoriasis: final results from 5 years of followup. Br J Dermatol. 2013;168(4):844-54. https://doi.org/10.1111/ bjd.12214.

39. Sofen H, Smith S, Matheson RT, Leonardi CL, Calderon $\mathrm{C}$, Brodmerkel C, et al. Guselkumab (an IL-23-specific $\mathrm{mAb}$ ) demonstrates clinical and molecular response in patients with moderate-to-severe psoriasis. J Allergy Clin Immunol. 2014;133(4):1032-40. https://doi.org/10.1016/j. jaci.2014.01.025.

40. Gordon KB, Duffin KC, Bissonnette R, Prinz JC, Wasfi Y, Li $\mathrm{S}$, et al. A phase 2 trial of guselkumab versus adalimumab for plaque psoriasis. N Engl J Med. 2015;373(2):136-44. https://doi. org/10.1056/NEJMoa1501646.

41. Blauvelt A, Papp KA, Griffiths CE, Randazzo B, Wasfi Y, Shen YK, et al. Efficacy and safety of guselkumab, an anti-interleukin-23 monoclonal antibody, compared with adalimumab for 
the continuous treatment of patients with moderate to severe psoriasis: results from the phase III, double-blinded, placeboand active comparator-controlled VOYAGE 1 trial. J Am Acad Dermatol. 2017;76(3):405-17. https://doi.org/10.1016/j. jaad.2016.11.041.

42. Reich K, Armstrong AW, Foley P, Song M, Wasfi Y, Randazzo $\mathrm{B}$, et al. Efficacy and safety of guselkumab, an anti-interleukin-23 monoclonal antibody, compared with adalimumab for the treatment of patients with moderate to severe psoriasis with randomized withdrawal and retreatment: results from the phase III, double-blind, placebo- and active comparator-controlled VOYAGE 2 trial. J Am Acad Dermatol. 2017;76(3):418-31. https:// doi.org/10.1016/j.jaad.2016.11.042.

43. Griffiths CEM, Papp KA, Song M, Miller M, You Y, Shen YK, et al. Continuous treatment with guselkumab maintains clinical responses through 4 years in patients with moderate-to-severe psoriasis: results from VOYAGE 1. J Dermatol Treat. 2020. https ://doi.org/10.1080/09546634.2020.1782817.

44. Reich K, Armstrong AW, Foley P, Song M, Miller M, Shen YK, et al. Maintenance of response through up to 4 years of continuous guselkumab treatment of psoriasis in the VOYAGE 2 phase 3 study. Am J Clin Dermatol. 2020;1(6):881-90. https:// doi.org/10.1007/s40257-020-00555-7.

45. Reich K, Armstrong AW, Langley RG, Flavin S, Randazzo B, Li S, et al. Guselkumab versus secukinumab for the treatment of moderate-to-severe psoriasis (ECLIPSE): results from a phase 3, randomised controlled trial. Lancet. 2019;394(10201):831-9. https://doi.org/10.1016/s0140-6736(19)31773-8.

46. Ohtsuki M, Kubo H, Morishima H, Goto R, Zheng R, Nakagawa H. Guselkumab, an anti-interleukin-23 monoclonal antibody, for the treatment of moderate to severe plaque-type psoriasis in Japanese patients: efficacy and safety results from a phase 3, randomized, double-blind, placebo-controlled study. J Dermatol. 2018;45(9):1053-62. https://doi.org/10.1111/1346-8138.14504.

47. Langley RG, Tsai TF, Flavin S, Song M, Randazzo B, Wasfi Y, et al. Efficacy and safety of guselkumab in patients with psoriasis who have an inadequate response to ustekinumab: results of the randomized, double-blind, phase III NAVIGATE trial. Br J Dermatol. 2018;178(1):114-23. https://doi.org/10.1111/bjd.15750.

48. Ferris LK, Ott E, Jiang J, Hong HC, Li S, Han C, et al. Efficacy and safety of guselkumab, administered with a novel patient-controlled injector (One-Press), for moderate-to-severe psoriasis: results from the phase 3 ORION study. J Dermatol Treat. 2020;31(2):152-9. https://doi.org/10.1080/09546 634.2019.1587145.

49. Papp K, Thaçi D, Reich K, Riedl E, Langley RG, Krueger JG, et al. Tildrakizumab (MK-3222), an anti-interleukin-23p19 monoclonal antibody, improves psoriasis in a phase IIb randomized placebo-controlled trial. Br J Dermatol. 2015;173(4):930-9. https ://doi.org/10.1111/bjd.13932.

50. Reich K, Papp KA, Blauvelt A, Tyring SK, Sinclair R, Thaçi $\mathrm{D}$, et al. Tildrakizumab versus placebo or etanercept for chronic plaque psoriasis (reSURFACE 1 and reSURFACE 2): results from two randomised controlled, phase 3 trials. Lancet. 2017;390(10091):276-88. https://doi.org/10.1016/s0140 -6736(17)31279-5.

51. Reich K, Warren RB, Iversen L, Puig L, Pau-Charles I, Igarashi A, et al. Long-term efficacy and safety of tildrakizumab for moderate-to-severe psoriasis: pooled analyses of two randomized phase III clinical trials (reSURFACE 1 and reSURFACE 2) through 148 weeks. Br J Dermatol. 2020;182(3):605-17. https ://doi.org/10.1111/bjd.18232.

52. Papp KA, Blauvelt A, Bukhalo M, Gooderham M, Krueger JG, Lacour JP, et al. Risankizumab versus ustekinumab for moderateto-severe plaque psoriasis. N Engl J Med. 2017;376(16):155160. https://doi.org/10.1056/NEJMoa1607017.
53. Gordon KB, Strober B, Lebwohl M, Augustin M, Blauvelt A, Poulin Y, et al. Efficacy and safety of risankizumab in moderate-to-severe plaque psoriasis (UltIMMa-1 and UltIMMa-2): results from two double-blind, randomised, placebo-controlled and ustekinumab-controlled phase 3 trials. Lancet. 2018;392(10148):650-61. https://doi.org/10.1016/s0140 $-6736(18) 31713-6$.

54. Reich K, Gooderham M, Thaçi D, Crowley JJ, Ryan C, Krueger $\mathrm{JG}$, et al. Risankizumab compared with adalimumab in patients with moderate-to-severe plaque psoriasis (IMMvent): a randomised, double-blind, active-comparator-controlled phase 3 trial. Lancet. 2019;394(10198):576-86. https://doi.org/10.1016/ s0140-6736(19)30952-3.

55. Warren RB, Blauvelt A, Poulin Y, Beeck S, Kelly M, Wu T, et al. Efficacy and safety of risankizumab vs. secukinumab in patients with moderate-to-severe plaque psoriasis (IMMerge): results from a phase 3, randomised, open-label, efficacy assessor-blinded clinical trial. Br J Dermatol. 2020. https://doi.org/10.1111/ bjd.19341.

56. Ohtsuki M, Fujita H, Watanabe M, Suzaki K, Flack M, Huang $\mathrm{X}$, et al. Efficacy and safety of risankizumab in Japanese patients with moderate to severe plaque psoriasis: results from the SustaIMM phase 2/3 trial. J Dermatol. 2019;46(8):686-94. https:// doi.org/10.1111/1346-8138.14941.

57. Blauvelt A, Leonardi CL, Gooderham M, Papp KA, Philipp S, $\mathrm{Wu}$ JJ, et al. Efficacy and safety of continuous risankizumab therapy vs treatment withdrawal in patients with moderate to severe plaque psoriasis: a phase 3 randomized clinical trial. JAMA Dermatol. 2020;156(6):1-11. https://doi.org/10.1001/ jamadermatol.2020.0723.

58. Reich K, Rich P, Maari C, Bissonnette R, Leonardi C, Menter A, et al. Efficacy and safety of mirikizumab (LY3074828) in the treatment of moderate-to-severe plaque psoriasis: results from a randomized phase II study. Br J Dermatol. 2019;181(1):88-95. https://doi.org/10.1111/bjd.17628.

59. Lilly's mirikizumab superior to Cosenty $x^{\circledR}$ (secukinumab) in a phase 3 study for patients with moderate to severe plaque psoriasis. https://investor.lilly.com/node/43481/pdf. Accessed 2 Aug 2020.

60. Ma C, Panaccione R, Khanna R, Feagan BG, Jairath V. IL12/23 or selective IL23 inhibition for the management of moderateto-severe Crohn's disease? Best Pract Res Clin Gastroenterol. 2019;38-39:101604. https://doi.org/10.1016/j.bpg.2019.02.006.

61. Gottlieb A, Menter A, Mendelsohn A, Shen YK, Li S, Guzzo C, et al. Ustekinumab, a human interleukin 12/23 monoclonal antibody, for psoriatic arthritis: randomised, double-blind, placebocontrolled, crossover trial. Lancet. 2009;373(9664):633-40. https ://doi.org/10.1016/s0140-6736(09)60140-9.

62. McInnes IB, Kavanaugh A, Gottlieb AB, Puig L, Rahman P, Ritchlin C, et al. Efficacy and safety of ustekinumab in patients with active psoriatic arthritis: 1 year results of the phase 3, multicentre, double-blind, placebo-controlled PSUMMIT 1 trial. Lancet. 2013;382(9894):780-9. https://doi.org/10.1016/s0140 -6736(13)60594-2.

63. Ritchlin C, Rahman P, Kavanaugh A, McInnes IB, Puig L, Li S, et al. Efficacy and safety of the anti-IL-12/23 p40 monoclonal antibody, ustekinumab, in patients with active psoriatic arthritis despite conventional non-biological and biological anti-tumour necrosis factor therapy: 6-month and 1-year results of the phase 3 , multicentre, double-blind, placebo-controlled, randomised PSUMMIT 2 trial. Ann Rheum Dis. 2014;73(6):990-9. https:// doi.org/10.1136/annrheumdis-2013-204655.

64. Araujo EG, Englbrecht M, Hoepken S, Finzel S, Kampylafka E, Kleyer A, et al. Effects of ustekinumab versus tumor necrosis factor inhibition on enthesitis: results from the enthesial clearance in psoriatic arthritis (ECLIPSA) study. Semin Arthritis 
Rheum. 2019;48(4):632-7. https://doi.org/10.1016/j.semarthrit .2018.05.011.

65. Deodhar A, Gensler LS, Sieper J, Clark M, Calderon C, Wang Y, et al. Three multicenter, randomized, double-blind, placebo-controlled studies evaluating the efficacy and safety of ustekinumab in axial spondyloarthritis. Arthritis Rheumatol. 2019;71(2):25870. https://doi.org/10.1002/art.40728.

66. Janssen. Tremfya ${ }^{\circledR}$ (guselkumab) approved by U.S. Food and Drug Administration as the first selective interleukin (IL)-23 inhibitor for active psoriatic arthritis. https://www.janssen.com/ us/sites/www_janssen_com_usa/files/tremfya_psa_fda_appro val_press_release_071420_final.pdf. Accessed 31 July 2020.

67. Deodhar A, Gottlieb AB, Boehncke WH, Dong B, Wang Y, Zhuang Y, et al. Efficacy and safety of guselkumab in patients with active psoriatic arthritis: a randomised, double-blind, placebo-controlled, phase 2 study. Lancet. 2018;391(10136):221324. https://doi.org/10.1016/s0140-6736(18)30952-8.

68. Deodhar A, Helliwell PS, Boehncke WH, Kollmeier AP, Hsia EC, Subramanian RA, et al. Guselkumab in patients with active psoriatic arthritis who were biologic-naive or had previously received TNF $\alpha$ inhibitor treatment (DISCOVER-1): a doubleblind, randomised, placebo-controlled phase 3 trial. Lancet. 2020;395(10230):1115-25. https://doi.org/10.1016/s0140 $-6736(20) 30265-8$.

69. Mease PJ, Rahman P, Gottlieb AB, Kollmeier AP, Hsia EC, Xu $\mathrm{XL}$, et al. Guselkumab in biologic-naive patients with active psoriatic arthritis (DISCOVER-2): a double-blind, randomised, placebo-controlled phase 3 trial. Lancet. 2020;395(10230):112636. https://doi.org/10.1016/s0140-6736(20)30263-4.

70. Mease PJ, Gladman DD, Deodhar A, McGonagle DG, Nash P, Boehncke WH, et al. Impact of guselkumab, an interleukin-23 p19 subunit inhibitor, on enthesitis and dactylitis in patients with moderate to severe psoriatic arthritis: results from a randomised, placebo-controlled, phase II study. RMD Open. 2020. https://doi. org/10.1136/rmdopen-2020-001217.

71. Langley RG, Thaçi D, Reich K, Papp K, Mehta A, Li Q, et al. FRI0445 tildrakizumab treatment improved measures of psoriatic arthritis in adults with chronic plaque psoriasis. Ann Rheum Dis. 2016;75(Suppl. 2):596. https://doi.org/10.1136/annrheumdi s-2016-eular.3342.

72. Ismail FF, May J, Moi J, Sinclair R. Clinical improvement in psoriatic nail disease and psoriatic arthritis with tildrakizumab treatment. Dermatol Ther. 2020;33(2):e13216. https://doi. org/10.1111/dth.13216.

73. Mease PJ, Chohan S, Fructuoso FJG, Chou RC, Nograles KE, Mendelsohn AM, et al. LB0002 Randomised, double-blind, placebo-controlled, multiple-dose, phase $2 \mathrm{~B}$ study to demonstrate the safety and efficacy of tildrakizumab, a high-affinity antiinterleukin-23p19 monoclonal antibody, in patients with active psoriatic arthritis. Ann Rheum Dis. 2019;78(Suppl. 2):78. https ://doi.org/10.1136/annrheumdis-2019-eular.8669.

74. Mease PJ, Kellner H, Morita A, Kivitz AJ, Papp KA, Aslanyan S, et al. OP0307 Efficacy and safety of risankizumab, a selective il-23p19 inhibitor, in patients with active psoriatic arthritis over 24 weeks: results from a phase 2 trial. Ann Rheum Dis. 2018;77(Suppl. 2):200. https://doi.org/10.1136/annrheumdi s-2018-eular.2140.

75. Baeten D, Østergaard M, Wei JC-C, Sieper J, Järvinen P, Tam L-S, et al. Risankizumab, an IL-23 inhibitor, for ankylosing spondylitis: results of a randomised, double-blind, placebocontrolled, proof-of-concept, dose-finding phase 2 study. Ann Rheum Dis. 2018;77(9):1295. https://doi.org/10.1136/annrh eumdis-2018-213328.

76. Sawyer LM, Malottki K, Sabry-Grant C, Yasmeen N, Wright E, Sohrt A, et al. Assessing the relative efficacy of interleukin-17 and interleukin-23 targeted treatments for moderate-to-severe plaque psoriasis: a systematic review and network meta-analysis of PASI response. PLoS ONE. 2019;14(8):e0220868. https ://doi.org/10.1371/journal.pone.0220868.

77. Du Jardin KG, Hurtado Lopez P, Lange M, McCool R, Maeso Naval S, Quickert S. A systematic literature review and Bucher indirect comparison: tildrakizumab versus guselkumab. J Health Econ Outcomes Res. 2020;7(2):123-9. https://doi. org/10.36469/jheor.2020.13671.

78. Zhou L, Wang Y, Wan Q, Perron D, Zhu R, Wang L, et al. 394 IL-23 antibodies in psoriasis: a non-clinical perspective. J Investig Dermatol. 2019;139(9 Suppl.):S282. https://doi. org/10.1016/j.jid.2019.07.396.

79. Kamaria M, Liao W, Koo JY. How long does the benefit of biologics last? An update on time to relapse and potential for rebound of biologic agents for psoriasis. Psoriasis Forum. 2010;16(2):36-42.

80. Warren RB, Carrascosa JM, Fumero E, Schoenenberger A, Lebwohl MG, Szepietowski JC, et al. Time to relapse after tildrakizumab withdrawal in patients with moderate-to-severe psoriasis who were responders at week 28: post-hoc analysis through 64 weeks from reSURFACE 1 trial. J Eur Acad Dermatol Venereol. 2020. https://doi.org/10.1111/jdv.16964.

81. Singh JA, Guyatt G, Ogdie A, Gladman DD, Deal C, Deodhar A, et al. 2018 American College of Rheumatology/National Psoriasis Foundation guideline for the treatment of psoriatic arthritis. Arthritis Care Res. 2019;71(1):2-29. https://doi. org/10.1002/acr.23789.

82. Piskin G, Sylva-Steenland RM, Bos JD, Teunissen MB. In vitro and in situ expression of IL-23 by keratinocytes in healthy skin and psoriasis lesions: enhanced expression in psoriatic skin. J Immunol. 2006;176(3):1908-15. https://doi.org/10.4049/ jimmunol.176.3.1908.

83. Hawkes JE, Yan BY, Chan TC, Krueger JG. Discovery of the IL-23/IL-17 signaling pathway and the treatment of psoriasis. J Immunol. 2018;201(6):1605-13. https://doi.org/10.4049/ jimmunol.1800013.

84. Guo W, Luo C, Wang C, Zhu Y, Wang X, Gao X, et al. Protection against Th17 cells differentiation by an interleukin-23 receptor cytokine-binding homology region. PLoS ONE. 2012;7(9):e45625. https://doi.org/10.1371/journal.pone.00456 25.

85. Abdo AIK, Tye GJ. Interleukin 23 and autoimmune diseases: current and possible future therapies. Inflamm Res. 2020;69(5):463-80. https://doi.org/10.1007/s00011-020-01339 -9 .

86. Girolomoni G, Strohal R, Puig L, Bachelez H, Barker J, Boehncke WH, et al. The role of IL-23 and the IL-23/T(H) 17 immune axis in the pathogenesis and treatment of psoriasis. $\mathbf{J}$ Eur Acad Dermatol Venereol. 2017;31(10):1616-26. https:// doi.org/10.1111/jdv.14433.

87. Kimball AB, Gordon KB, Fakharzadeh S, Yeilding N, Szapary PO, Schenkel B, et al. Long-term efficacy of ustekinumab in patients with moderate-to-severe psoriasis: results from the PHOENIX 1 trial through up to 3 years. Br J Dermatol. 2012;166(4):861-72. https://doi.org/10.111 1/j.1365-2133.2012.10901.x.

88. Maliyar K, O'Toole A, Gooderham MJ. Long-term single center experience in treating plaque psoriasis with guselkumab. J Cutan Med Surg. 2020. https://doi.org/10.1177/1203475420 932514.

89. Blauvelt A, Papp K, Gottlieb A, Jarell A, Reich K, Maari C, et al. A head-to-head comparison of ixekizumab vs. guselkumab in patients with moderate-to-severe plaque psoriasis: 12-week efficacy, safety and speed of response from a randomized, doubleblinded trial. Br J Dermatol. 2020;182(6):1348-58. https://doi. org/10.1111/bjd.18851. 
90. Levin AA, Gottlieb AB. Specific targeting of interleukin23p19 as effective treatment for psoriasis. J Am Acad Dermatol. 2014;70(3):555-61. https://doi.org/10.1016/j. jaad.2013.10.043.

91. Gately MK, Renzetti LM, Magram J, Stern AS, Adorini L, Gubler U, et al. The interleukin-12/interleukin-12-receptor system: role in normal and pathologic immune responses. Annu Rev Immunol. 1998;16:495-521. https://doi.org/10.1146/annur ev.immunol.16.1.495.

92. Crowley JJ, Warren RB, Cather JC. Safety of selective IL-23p19 inhibitors for the treatment of psoriasis. J Eur Acad Dermatol Venereol. 2019;33(9):1676-84. https://doi.org/10.1111/ jdv. 15653 .

93. Zhu Y, Hu C, Lu M, Liao S, Marini JC, Yohrling J, et al. Population pharmacokinetic modeling of ustekinumab, a human monoclonal antibody targeting IL-12/23p40, in patients with moderate to severe plaque psoriasis. J Clin Pharmacol. 2009;49(2):162-75. https://doi.org/10.1177/0091270008329556.

94. Zhu Y, Xu Y, Zhuang Y, Piantone A, Shu C, Chen D, et al. Evaluating potential disease-mediated protein-drug interactions in patients with moderate-to-severe plaque psoriasis receiving subcutaneous guselkumab. Clin Transl Sci. 2020. https://doi. org/10.1111/cts.12807.

95. Khalilieh S, Hussain A, Montgomery D, Levine V, Shaw PM, Bodrug I, et al. Effect of tildrakizumab (MK-3222), a high affinity, selective anti-IL23p19 monoclonal antibody, on cytochrome P450 metabolism in subjects with moderate to severe psoriasis. Br J Clin Pharmacol. 2018;84(10):2292-302. https://doi. org/10.1111/bcp.13670.

96. Khatri A, Cheng L, Camez A, Ignatenko S, Pang Y, Othman AA. Lack of effect of 12-week treatment with risankizumab on the pharmacokinetics of cytochrome $\mathrm{P} 450$ probe substrates in patients with moderate to severe chronic plaque psoriasis. Clin Pharmacokinet. 2019;58(6):805-14. https://doi.org/10.1007/ s40262-018-0730-x.

97. Evangelatos G, Koulouri V, Iliopoulos A, Fragoulis GE. Tuberculosis and targeted synthetic or biologic DMARDs, beyond tumor necrosis factor inhibitors. Ther Adv Musculoskelet Dis. 2020. https://doi.org/10.1177/1759720x20930116.

98. Fowler E, Ghamrawi RI, Ghiam N, Liao W, Wu JJ. Risk of tuberculosis reactivation during interleukin-17 inhibitor therapy for psoriasis: a systematic review. J Eur Acad Dermatol Venereol. 2020;34(7):1449-56. https://doi.org/10.1111/jdv.16254.

99. Khader SA, Cooper AM. IL-23 and IL-17 in tuberculosis. Cytokine. 2008;41(2):79-83. https://doi.org/10.1016/j. cyto.2007.11.022.

100. Tsai TF, Ho V, Song M, Szapary P, Kato T, Wasfi Y, et al. The safety of ustekinumab treatment in patients with moderate-to-severe psoriasis and latent tuberculosis infection. Br J Dermatol. 2012;167(5):1145-52. https://doi.org/10.111 1/j.1365-2133.2012.11142.x.

101. Puig L, Tsai TF, Bhutani T, Uy J, Ramachandran P, Song M, et al. Safety in moderate-to-severe plaque psoriasis patients with latent tuberculosis treated with guselkumab and anti-tuberculosis treatments concomitantly: results from pooled phase 3 VOYAGE 1 \& VOYAGE 2 trials. J Eur Acad Dermatol Venereol. 2020;34(8):1744-9. https://doi.org/10.1111/jdv.16460.

102. Ryan C, Leonardi CL, Krueger JG, Kimball AB, Strober BE, Gordon KB, et al. Association between biologic therapies for chronic plaque psoriasis and cardiovascular events: a meta-analysis of randomized controlled trials. JAMA. 2011;306(8):864-71. https://doi.org/10.1001/jama.2011.1211.

103. Reich K, Langley RG, Lebwohl M, Szapary P, Guzzo C, Yeilding N, et al. Cardiovascular safety of ustekinumab in patients with moderate to severe psoriasis: results of integrated analyses of data from phase II and III clinical studies.
Br J Dermatol. 2011;164(4):862-72. https://doi.org/10.111 1/j.1365-2133.2011.10257.x.

104. Tzellos T, Kyrgidis A, Zouboulis CC. Re-evaluation of the risk for major adverse cardiovascular events in patients treated with anti-IL-12/23 biological agents for chronic plaque psoriasis: a meta-analysis of randomized controlled trials. J Eur Acad Dermatol Venereol. 2013;27(5):622-7. https://doi.org/10.111 $1 / \mathrm{j} .1468-3083.2012 .04500$.x.

105. Gordon KB, Langley RG, Gottlieb AB, Papp KA, Krueger GG, Strober BE, et al. A phase III, randomized, controlled trial of the fully human IL-12/23 mAb briakinumab in moderate-to-severe psoriasis. J Invest Dermatol. 2012;132(2):304-14. https://doi. org/10.1038/jid.2011.304.

106. Dommasch ED, Troxel AB, Gelfand JM. Major cardiovascular events associated with anti-IL 12/23 agents: a tale of two metaanalyses. J Am Acad Dermatol. 2013;68(5):863-5. https://doi. org/10.1016/j.jaad.2013.01.011.

107. Poizeau F, Nowak E, Kerbrat S, Le Nautout B, Droitcourt C, Drici MD, et al. Association between early severe cardiovascular events and the initiation of treatment with the anti-interleukin 12/23p40 antibody ustekinumab. JAMA Dermatol. 2020. https ://doi.org/10.1001/jamadermatol.2020.2977.

108. Lebwohl M, Rivera-Oyola R, Murrell DF. Should biologics for psoriasis be interrupted in the era of COVID-19? J Am Acad Dermatol. 2020;82(5):1217-8. https://doi.org/10.1016/j. jaad.2020.03.031.

109. Price KN, Frew JW, Hsiao JL, Shi VY. COVID-19 and immunomodulator/immunosuppressant use in dermatology. J Am Acad Dermatol. 2020;82(5):e173-5. https://doi.org/10.1016/j. jaad.2020.03.046.

110. Fieldhouse KA, Ukaibe S, Crowley EL, Khanna R, O'Toole A, Gooderham MJ. Inflammatory bowel disease in patients with psoriasis treated with interleukin-17 inhibitors. Drugs Context. 2020. https://doi.org/10.7573/dic.2020-2-1.

111. Macaluso FS, Orlando A, Cottone M. Anti-interleukin-12 and anti-interleukin-23 agents in Crohn's disease. Expert Opin Biol Ther. 2019;19(2):89-98. https://doi.org/10.1080/14712 598.2019.1561850.

112. Conti HR, Gaffen SL. IL-17-mediated immunity to the opportunistic fungal pathogen Candida albicans. J Immunol. 2015;195(3):780-8. https://doi.org/10.4049/jimmunol.1500909.

113. Menter A, Strober BE, Kaplan DH, Kivelevitch D, Prater EF, Stoff B, et al. Joint AAD-NPF guidelines of care for the management and treatment of psoriasis with biologics. J Am Acad Dermatol. 2019;80(4):1029-72. https://doi.org/10.1016/j. jaad.2018.11.057.

114. Siegel SAR, Winthrop KL, Ehst BD, Ortega LA. Ustekinumab use in patients with severe psoriasis co-infected with hepatitis B and/or C. Br J Dermatol. 2019;180(5):1232-3. https://doi. org/10.1111/bjd.17444.

115. Solay AH, Acar A, Eser F, Kuşcu F, Tütüncü EE, Kul G, et al. Reactivation rates in patients using biological agents, with resolved $\mathrm{HBV}$ infection or isolated anti-HBc IgG positivity. Turk J Gastroenterol. 2018;29(5):561-5. https://doi.org/10.5152/ tjg.2018.18032.

116. Ting SW, Chen YC, Huang YH. Risk of hepatitis B reactivation in patients with psoriasis on ustekinumab. Clin Drug Investig. 2018;38(9):873-80. https://doi.org/10.1007/s40261-018-0671-z.

117. Bartos G, Cline A, Beroukhim K, Burrall BA, Feldman SR. Current biological therapies for use in HIV-positive patients with psoriasis: case report of gesulkumab used and review. Dermatol Online J. 2018;24(11):13030/qt3db748cg.

118. Montes-Torres A, Aparicio G, Rivera R, Vilarrasa E, Marcellán M, Notario J, et al. Safety and effectiveness of conventional systemic therapy and biological drugs in patients with moderate to severe psoriasis and HIV infection: a retrospective 
multicenter study. J Dermatol Treat. 2019;30(5):461-5. https:// doi.org/10.1080/09546634.2018.1535690.

119. Stelara ${ }^{\circledR}$ (ustekinumab) [package insert]. Horsham (PA): Janssen; 2016.

120. Tremfya ${ }^{\circledR}$ (guselkumab) [package insert]. Horsham (PA): Janssen; 2017.

121. Ilumya ${ }^{\circledR}$ (tildrakizumab-asmn) [package insert]. Whitehouse Station (NJ): Merck; 2018.

122. Skyrizi ${ }^{\circledR}$ (risankizumab-rzaa) [package insert]. North Chicago (IL): AbbVie; 2019.
123. Tyring SK, Spelman L, Igarashi A, Ohtsuki M, Ciichanowitz $\mathrm{N}$, La Rosa C, et al. Efficacy and safety of long-term tildrakizumab for plaque psoriasis: 3-year results from reSURFACE 1. J Am Acad Dermatol. 2019;81(4 Suppl. 1):AB431. https://doi. org/10.1016/j.jaad.2019.10.026.

124. Gooderham M, Papp KA, Blauvelt A, Thaçi D, Ciichanowitz $\mathrm{N}, \mathrm{Li} \mathrm{Q}$, et al. Efficacy and safety of long-term tildrakizumab for plaque psoriasis: 3-year results from reSURFACE 2. J Am Acad Dermatol. 2019;81(4):AB431. https://doi.org/10.1016/j. jaad.2019.10.027. 